\title{
Recent advances in one-dimensional nanostructures for energy electrocatalysis
}

\author{
Ping Li a,b, Wei Chen a,b,* \\ a State Key Laboratory of Electroanalytical Chemistry, Changchun Institution of Applied Chemistry, Chinese Academic of Sciences, Changchun 130022 , \\ Jilin, China \\ ${ }^{\mathrm{b}}$ School of Applied Chemistry and Engineering, University of Science and Technology of China, Hefei 230026, Anhui, China
}

\section{A R T I C L E I N F}

\section{Article history:}

Received 31 August 2018

Accepted 8 October 2018

Published 5 January 2019

\section{Keywords:}

One-dimensional nanostructure

Fuel cell

Water splitting

Electrocatalysis

Energy conversion

\begin{abstract}
A B S T R A C T
Catalysts play decisive roles in determining the energy conversion efficiencies of energy devices. Up to now, various types of nanostructured materials have been studied as advanced electrocatalysts. This review highlights the application of one-dimensional (1D) metal electrocatalysts in energy conversion, focusing on two important reaction systems-direct methanol fuel cells and water splitting. In this review, we first give a broad introduction of electrochemical energy conversion. In the second section, we summarize the recent significant advances in the area of 1D metal nanostructured electrocatalysts for the electrochemical reactions involved in fuel cells and water splitting systems, including the oxygen reduction reaction, methanol oxidation reaction, hydrogen evolution reaction, and oxygen evolution reaction. Finally, based on the current studies on 1D nanostructures for energy electrocatalysis, we present a brief outlook on the research trend in 1D nanoelectrocatalysts for the two clean electrochemical energy conversion systems mentioned above.
\end{abstract}

(C) 2019, Dalian Institute of Chemical Physics, Chinese Academy of Sciences. Published by Elsevier B.V. All rights reserved.

\section{Introduction}

With the fast development of human society, the increasing consumption of fossil fuels has resulted in serious environmental degradation and global warming $[1,2]$. The International Energy Agency reported that in 2017 the total primary energy supplied by fuels has increased up to 13647 Mtoe globally and is still increasing year-on-year. It should be noted that the major energy supply is from non-renewable energy resources such as coal, oil, and natural gas. To confront the abovementioned issues, it is necessary to develop clean, renewable, highly efficient energy conversion strategies for replacing fossil fuels [3-5]. Electrocatalysis, as a part of electrochemistry, is closely related to electrochemical energy conversion, functional material synthesis, environmental protection, and other relevant industries, and enables the sustainable development of future technologies [1,3]. Currently, direct methanol fuel cells (DMFCs) and water splitting (WS) have been recognized as two promising new energy and renewable energy technologies that have received increasing interest owing to their advantages such as high efficiencies, low pollutant emissions, and mild operational conditions [6-9]. However, the wide commercialization of the two types of energy conversion techniques is limited by their slow dynamic processes, low catalytic performances, and poor stabilities of the catalysts. Therefore, the crucial challenges encountered in DMFCs and WS are how to

\footnotetext{
*Corresponding author. Tel/Fax: +86-431-85262723; E-mail: weichen@ciac.ac.cn

This work was supported by the National Natural Science Foundation of China $(21575134,21633008,21773224)$, National Key R\&D Program of China (2016YFA0203200), and K. C. Wong Education Foundation.

DOI: 10.1016/S1872-2067(18)63177-8 | http://www.sciencedirect.com/science/journal/18722067 | Chin. J. Catal., Vol. 40, No. 1, January 2019
} 
enhance the catalytic performance and appropriately balance the efficiency and selectivity of electrocatalysts for the chemical transformations involved. From the point of view of catalytic processes, a DMFC involves two half-reactions (Fig. 1(a)), namely, methanol oxidation reaction (MOR) and oxygen reduction reaction (ORR). For the scheme of methanol oxidation on the anode and oxygen reduction on the cathode, electrons migrate from the anode to the cathode, which results in the protons also flowing from the anode to the cathode in order to maintain the charge balance of the electrolyte solution; thus the chemical energy is converted into electrical energy. On the other hand, WS, which requires a theoretical potential of about $1.23 \mathrm{~V}$, consists of the following two half-reactions: hydrogen evolution reaction (HER; occurring at the cathode) and oxygen evolution reaction (OER; occurring at the anode) (Fig. 1(b)). Regarding the commercialization of these energy devices, the electrocatalysts currently developed for the four abovementioned half-reactions have certain critical limitations. The main challenge arises from the large overpotentials $(\eta)$ of the pair reactions occurring in the systems (the sluggish anodic MOR/OER and the cathodic ORR/HER). Therefore, it is urgent that outstanding electrocatalysts with high activities and stabilities are developed and that the related reaction mechanisms are fully understood.

The two fundamental strategies to improve the activity of an electrocatalyst system and thus minimizing the overpotentials of the electrode reactions are (1) increasing the number of active sites per unit area and (2) increasing the inherent activity of each active site, e.g., by exposing the special high-index surface planes. Although remarkable progress has been made in the design of catalysts, there is still substantial room for improvement. Among the various catalytic materials, metal nanomaterials, especially noble-metal nanostructures, display great potential for the catalytic field. Compared with the corresponding bulk metal materials, the metal nanostructured materials normally exhibit larger specific surface/interface areas and expose more reactive sites, and therefore, possess superior catalytic activities. Currently, carbon black-supported zero-dimensional Pt nanoparticles $(\mathrm{Pt} / \mathrm{C}$ ) have been widely used in energy electrocatalysis. However, owing to surface energy minimization and Ostwald ripening, the corrosion of the carbon carrier at high potentials may cause the loss and aggregation of the Pt nanoparticles. In addition, as a class of unique structured

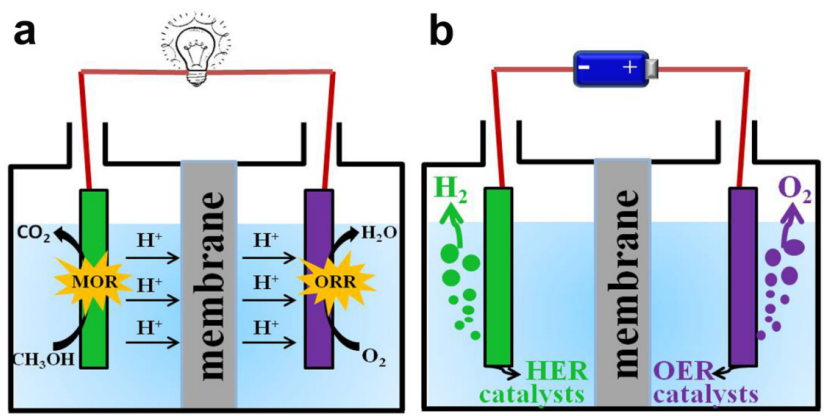

Fig. 1. Schematic representations of electrochemical energy devices. (a) Direct methanol fuel cell-a single cell with MOR and ORR; (b) a water splitting system involving the HER and the OER. materials, metal single atom catalysts have attracted increasing attention in recent years owing to the maximum atomic utilization and their high efficiencies in the electrochemical energy conversion and storage processes [10-14]. However, the single atom catalysts generally have to be embedded within various matrices, including metals, metal oxides, and carbon materials. These substrates often have great influences on their catalytic performances, and the minimal amounts of the active materials in the matrices results in low current densities, which is not suitable for practical applications [15-17]. Different from nanoparticle and single atom catalysts, one-dimensional (1D) nanostructures reveal numerous unique structural advantages and superior surface properties, and therefore, exhibit enhanced electrocatalytic activity and stability [18,19]. 1D nanostructures such as nanowires (NWs), nanotubes, nanobelts, and core-shell nanostructures have been recognized as a class of ideal structures that have promising applications in numerous areas, such as electronic and magnetic devices, optoelectronic devices, transparent and stretchable electrodes, and electrochemical devices [20,21]. Rational design of well-defined functional 1D nanostructures can maximize their structural advantages and properties. Recently, various types of 1D nanostructured electrocatalysts have been synthesized, which can be roughly classified into two categories: (I) 1D Pt-based nanostructures, and (II) 1D non-Pt-based nanostructures, which mainly include transition metals ( $\mathrm{Mo}, \mathrm{Cu}, \mathrm{Mn}, \mathrm{Ni}, \mathrm{Co}, \mathrm{Fe}$ ) and non-metals (C, N, S, P, Se). These developed 1D materials and the related theoretical studies provide the possible ways for catalyst optimization that can lead to their application in future not only in fuel cells and WS electrochemical energy conversion devices but also in environmental catalysis and biocatalysis, apart from other vital chemical reactions.

In this review, we first introduce and elaborate the four half-reactions and the reaction procedures involved in fuel cells and WS. Then, we summarize and discuss the recent developments on 1D nanomaterials as electrocatalysts for the ORR, MOR, HER, and OER. Finally, the future developments in this research area are also predicted.

\section{One-dimensional (1D) metal nanostructured electrocatalysts}

\subsection{D nanostructured catalysts for the ORR}

A fuel cell is a promising clean energy conversion device; however, the sluggish kinetics of the cathodic ORR is still a great challenge that affects its practical application and commercialization [22]. Hence, it is of importance to develop more efficient electrocatalysts for the ORR. Meanwhile, in-depth understanding of the ORR mechanism will be helpful in rationally designing electrocatalysts. Normally, the ORR follows two pathways: (1) direct four-electron reduction, which involves complex intermediates $\left(\mathrm{O}^{*}, \mathrm{OH}^{*}, \mathrm{OOH}^{*}\right)$ and is a desirable pathway for fuel cells, and (2) indirect two-electron reduction, with $\mathrm{H}_{2} \mathrm{O}_{2}$ as the intermediate. In these processes, $\mathrm{O}_{2}$ is converted into $\mathrm{H}_{2} \mathrm{O}$ or $\mathrm{OH}^{-}$, depending on the nature of the electrolyte solution used [7,23-25]. The related reactions can be de- 
scribed as follows.

$4 \mathrm{e}^{-}$process:

In an acidic medium: $\mathrm{O}_{2}+4 \mathrm{H}^{+}+4 \mathrm{e}^{-} \rightarrow 2 \mathrm{H}_{2} \mathrm{O}$

In an alkaline medium: $\mathrm{O}_{2}+2 \mathrm{H}_{2} \mathrm{O}+4 \mathrm{e}^{-} \rightarrow 4 \mathrm{OH}^{-}$

$2 \mathrm{e}^{-}$process:

In an acidic medium: $\mathrm{O}_{2}+2 \mathrm{H}^{+}+2 \mathrm{e}^{-} \rightarrow \mathrm{H}_{2} \mathrm{O}_{2}$

$$
\mathrm{H}_{2} \mathrm{O}_{2}+2 \mathrm{H}^{+}+2 \mathrm{e}^{-} \rightarrow 2 \mathrm{H}_{2} \mathrm{O}
$$

In an alkaline medium: $\mathrm{O}_{2}+\mathrm{H}_{2} \mathrm{O}+2 \mathrm{e}^{-} \rightarrow \mathrm{HO}_{2}{ }^{-}+\mathrm{OH}^{-}$

$$
\mathrm{HO}_{2}^{-}+\mathrm{H}_{2} \mathrm{O}+2 \mathrm{e}^{-} \rightarrow 3 \mathrm{OH}^{-}
$$

According to the Sabatier principle, an excellent catalyst should have balanced adsorption and desorption energies for the key reaction intermediates. In the ORR reaction, too weak or too strong a binding of the $\mathrm{O}$ on metal catalysts is unfavorable for catalysis. If adsorbed weakly, the associative mechanism of electron transfer to $\mathrm{O}_{2}$ * or the dissociative mechanism of the splitting of the $\mathrm{O}-\mathrm{O}$ bond of $\mathrm{O}_{2}$ may limit the reaction rate and efficiency; on the contrary, in the case of strong absorption, electron transfer to $\mathrm{O}^{*}$ or $\mathrm{OH}^{*}$ may become the limiting step. A volcano-type plot (Fig. 2(a)) has been established for relating the surface adsorption energies $\Delta E_{0}$ with the catalytic activities of the given materials for the ORR, which provides a new avenue for optimizing electrocatalysts for the ORR [26-28].

\subsubsection{D Pt-based nanostructures for the ORR}

Up to now, Pt metal has exhibited superior ORR catalytic performances than others, and the kinetic calculations revealed that the ORR on Pt occurs mainly via the four-electron transfer process in both acidic and alkaline media. Owing to the easy electron flow, intrinsically high stability, and ready exposure of the high-index active crystal planes, 1D Pt-based nanostructures show high catalytic activities for the ORR, irrespective of whether they are in the alloy form or the core/shell form. There are several effective strategies for improving the activity and stability of ORR catalysts [29-31]: (1) tailoring or controlling the shape of the catalyst; (2) enlarging the active area or improving the activity of the sites; (3) doping or alloying with other components; (4) controlling the surface components; and (5) loading the catalyst on special supports. For example, ac-
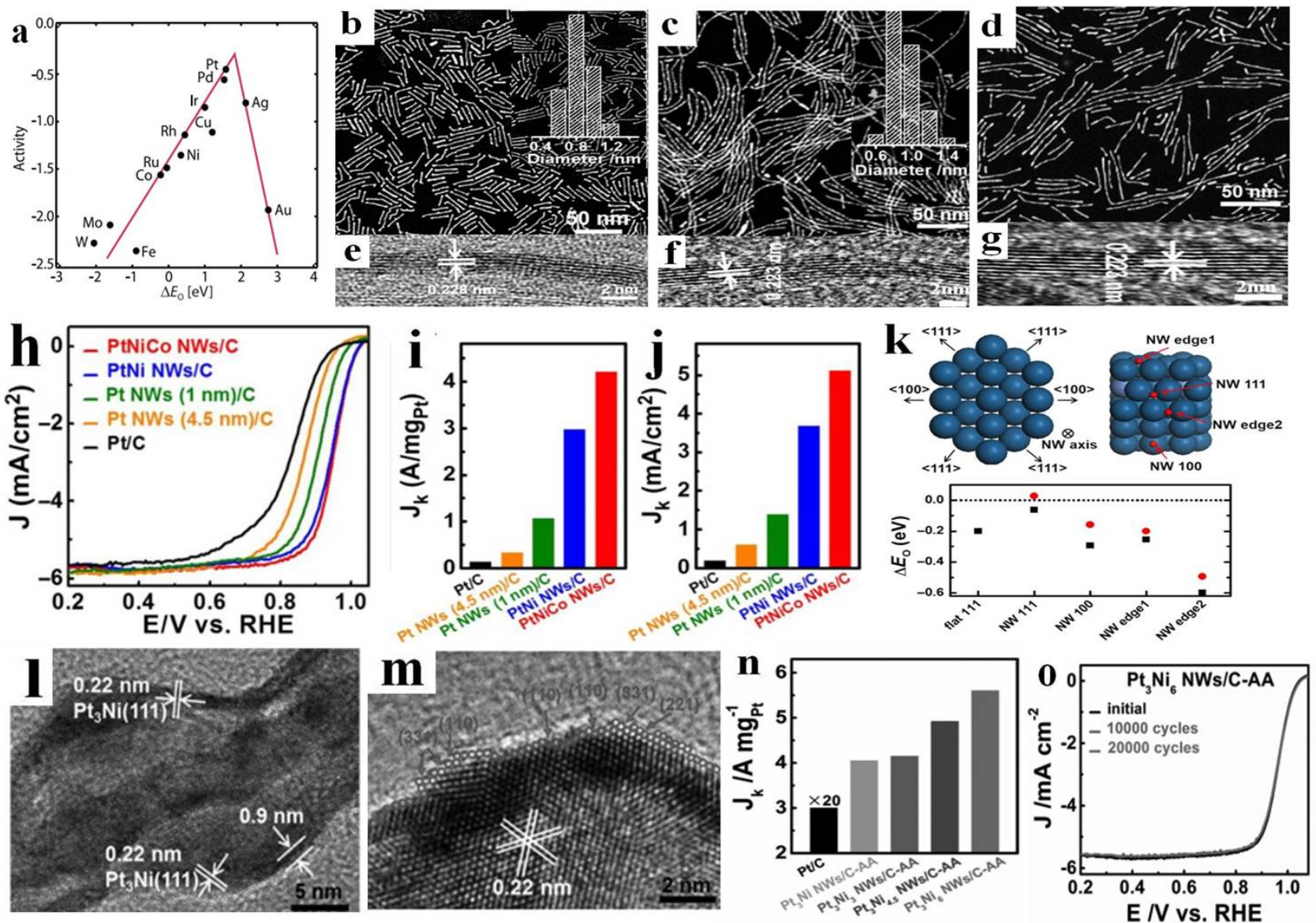

Fig. 2. (a) ORR volcano plot displaying the oxygen reduction activities of different metals. Reprinted with permission from Ref. [27] Copyright American Chemical Society. (b-g) Morphologies and structures of sub-nanometer-sized Pt NWs, PtNi NWs, and PtNiCo NWs: (b-d) STEM images; (e-g) HRTEM images. The right insets in (b, c) show the histograms of the diameters of the NWs. (h) The ORR polarization curves for the different NWs obtained at a sweep rate of $10 \mathrm{mV} / \mathrm{s}$ and a rotation rate of $1600 \mathrm{rpm}$. (i, j) The mass activities and specific activities of the NWs for the ORR. (k) DFT calculations of $\Delta E_{0}$ and the atomic model of the single crystalline NWs with four (111) facets and two (100) facets. There are four stable adsorption sites for oxygen on the NWs. The red spheres represent oxygen atoms (Fig. 2(k) right). The bottom plot of Fig. 2(k) shows $\Delta E_{0}$ on a flat Pt (111) surface and the Pt-based NWs. The black squares and red circles correspond to the $\Delta E_{0}$ values on the pure Pt and PtNi NWs, respectively. The horizontal dashed line indicates the optimal $\Delta E_{0}$ value. Reproduced from Ref. [32] with permission from Science. (l-o) Morphology and ORR catalytic performance of $\mathrm{Pt}_{3} \mathrm{Ni}_{6}$ NWs/C-AA. (l, m) HRTEM images. (n) Mass activities. (o) Stability tests with the ORR polarization curves. Reproduced from Ref. [33] with permission from Wiley-VCH. 
cording to density functional theory (DFT) calculations, in $\mathrm{HClO}_{4}$ solution, the ORR activity increases in the order of $\mathrm{Pt}$ $[110]<$ Pt [100] < Pt [111] < Pt with high-index facets. Therefore, 1D Pt NWs with [111] facets have been studied as a new type of electrocatalysts for the ORR.

In 2017, Huang and coworkers reported a series of sub-nanometer Pt and Pt alloy NWs with different compositions: Pt NWs, PtNi NWs, and PtNiCo NWs [32]. The synthesized NWs exhibited enhanced catalytic performances for the ORR in terms of both activities and stabilities. The Pt NWs, PtNi, and PtNiCo alloy NWs are about $0.8 \mathrm{~nm}$ in diameter, which corresponds to a thickness of only 4-5 atomic layers, and the length of the PtNiCo alloy NWs can be controlled through the amount of $\mathrm{Mo}(\mathrm{CO})_{6}$ added, which varied from 9 to $35 \mathrm{~nm}$ (Fig. 2(b)-(d)). As shown in the HRTEM images of Fig. 2(e)-(g), the NWs crystallize in the face-centered cubic (fcc) structure and are enclosed by the [111] planes. Fig. 2(h) shows the linear voltammetry polarization curves of the ORR on the NW catalysts, which were recorded in $\mathrm{O}_{2}$-saturated $0.1 \mathrm{M} \mathrm{HClO}_{4}$ at room temperature. It can be obviously seen that the half-wave potentials of the sub-nanometer Pt and Pt alloy NWs are more positive than that of the commercial Pt/C. In Fig. 2(i) and (j), the PtNiCo NWs exhibit mass activities and specific activities that are a dozen times those of the commercial Pt/C, which could be ascribed to the exposed [111] facets. Accelerated durability tests (ADT) were performed between 0.6 and $1.1 \mathrm{~V}$ vs RHE to examine the electrochemical stabilities of the NW catalysts in $0.1 \mathrm{M} \mathrm{HClO}_{4}$. The results revealed that PtNi NW/C and PtNiCo $\mathrm{NW} / \mathrm{C}$ only showed small decreases in their initial electrochemical active surface area (ECSA) and mass activity after 30000 cycles, indicating their much higher stabilities compared to that of the commercial Pt/C. The related DFT calculations (Fig. 2(k)) indicate that the active [111] facets of the sub-nanometer Pt NWs contribute to the high ORR catalytic activity. Meanwhile, the heteroatom Ni could modulate the $\Delta E_{0}$ (the difference between a given $E_{0}$ and the optimal value), thus reducing the adsorption energy of oxygen on the catalysts and boosting the ORR activity. In the same year, the authors also reported another type of composition-segregated porous $\mathrm{Pt}_{3} \mathrm{Ni}$ NWs with high-index facets and an ultrathin Pt shell [33]. After the process of sacrificial component etching with acetic acid (Fig. 2(l) and (m)), the unstable Ni species can be selectively removed, and the numerous high-index planes of [110], [221], and [331] are exposed. The obtained porous $\mathrm{Pt}_{3} \mathrm{Ni}_{6} \mathrm{NWs}$ with a Pt-rich shell, uneven surfaces, and high aspect ratios $(\sim 100)$ exhibited a superior ORR activity $(5.60 \mathrm{~A} / \mathrm{mg})$ that was 37 times that of the commercial $\mathrm{Pt} / \mathrm{C}(0.15 \mathrm{~A} / \mathrm{mg})$ and excellent stability, with $93.6 \%$ of the activity remaining after 20000 cycles (Fig. 2(n) and (o)).

In another study, Wu and coworkers [34] investigated the growth mechanism of Pt NWs with the help of in situ TEM. Through a clear growth mechanism, the catalytic activity of the materials can be effectively improved and the shape can be controlled at the atomic level. In this research, the authors found that the NW growth involves three steps: nucleation, crystal growth, and attachment of small particles. (Fig. 3(a)) Free-standing NWs were obtained through the generic gas-solid technique with the assistance of $\mathrm{H}_{2}$. The growth begins with small nuclei, which grow and show a tendency to coalesce in $10 \mathrm{~min}$. Some particles then adhere together to form distinctive NWs in 20 min. Finally, free-standing NWs are successfully obtained in $30 \mathrm{~min}$ (Fig. 3(b)). During the growth, the in situ TEM study illustrated that surface diffusion and particle attachment along a specific orientation ([110] planes) are the main formation mechanism of the Pt NWs. Based on this mechanism, by simply modifying the approach by adding an appropriate amount of $\mathrm{NiCl}_{2} \cdot 6 \mathrm{H}_{2} \mathrm{O}$ to the pre-treatment step, ultrathin $\mathrm{Pt}_{1.3} \mathrm{Ni}$ NWs could also be obtained (Fig. 3(c)). Electrochemical studies showed that although the surface areas of the $\mathrm{Pt}$ and $\mathrm{Pt}_{1.3} \mathrm{Ni}$ NWs are smaller than that of the commercial $\mathrm{Pt} / \mathrm{C}$, their half-wave potentials for the ORR are superior to that of Pt/C, with positive shifts of 86 and $108 \mathrm{mV}$, respectively. The prepared nanowires also exhibited greater stability than $\mathrm{Pt} / \mathrm{C}$ (Fig. 3(d) and (e)). The excellent ORR catalytic performances could be ascribed to the exposure of the Pt [111] planes, together with the merits of 1D nanostructures. Meanwhile, Gao and coworkers [35] synthesized a Pt nanotube catalyst with ultrathin walls and a high aspect ratio. The nanotubes preserved the morphology of the template perfectly without any disaggregation and revealed growth along the [110] direction. The thickness and diameter of these Pt nanotubes are about 1 and $5.5 \mathrm{~nm}$, respectively, with the length being up to the micrometer scale (Fig. 3(f)). The Pt nanotubes exhibit a large ECSA of about $91.43 \mathrm{~m}^{2} / \mathrm{g}_{\mathrm{Pt}}$ owing to the hollow helix structure. These nanotubes have been proved to be a more efficient catalyst for the ORR than the commercial Pt/C (Fig. 3(g) and (h)).

Apart from the activity, the stability or durability is another important parameter for evaluating the performance of a catalyst. Incorporating certain metals into Pt-based catalysts has become a favorable method to improve the durability [36-38]. For example, Zeng and partners reported Rh-doped Pt NWs to be an extraordinary ORR catalyst [39]. Combining the advantages of the 1D anisotropic nanostructure, high utilization of Pt atoms, doped Rh atoms, and interaction between the two types of atoms, the as-synthesized NWs exhibited superior activity and durability for the ORR. According to the studies on the formation mechanism, the nanocrystals first grow anisotropically to form NWs and then template-directed growth and/or defect-induced growth occurs, which results in fcc metal nanocrystals. The EXAFS results confirmed the ultrafine diameter of the NWs and the tiny radius of the Rh atoms. The length of the Pt-Pt bond decreased about $\sim 0.7 \%$ compared with that in a Pt foil $(2.76 \AA$ ) , and this compressive strain in turn contributed to the enhanced specific activity. DFT calculations were also performed, and the $d$-band center of $\mathrm{Pt}_{7} \mathrm{Rh}$ [111] downshifted; a weaker $\Delta E_{\mathrm{OH}}$ can rationalize the higher ORR activity of the Rh-doped Pt NWs. Hence, the high ORR activity and stability may be derived from (1) the exposure of special planes, such as Pt [111], which is the main facet on the surface of 1D nanostructures with higher activity/stability than the NPs; (2) the hollow 1D structure obtained by the etching process, which enlarges the surface that is beneficial for enhancing mass transport and improving the electronic conductivity; (3) the charge transfer and compressive strain resulting 


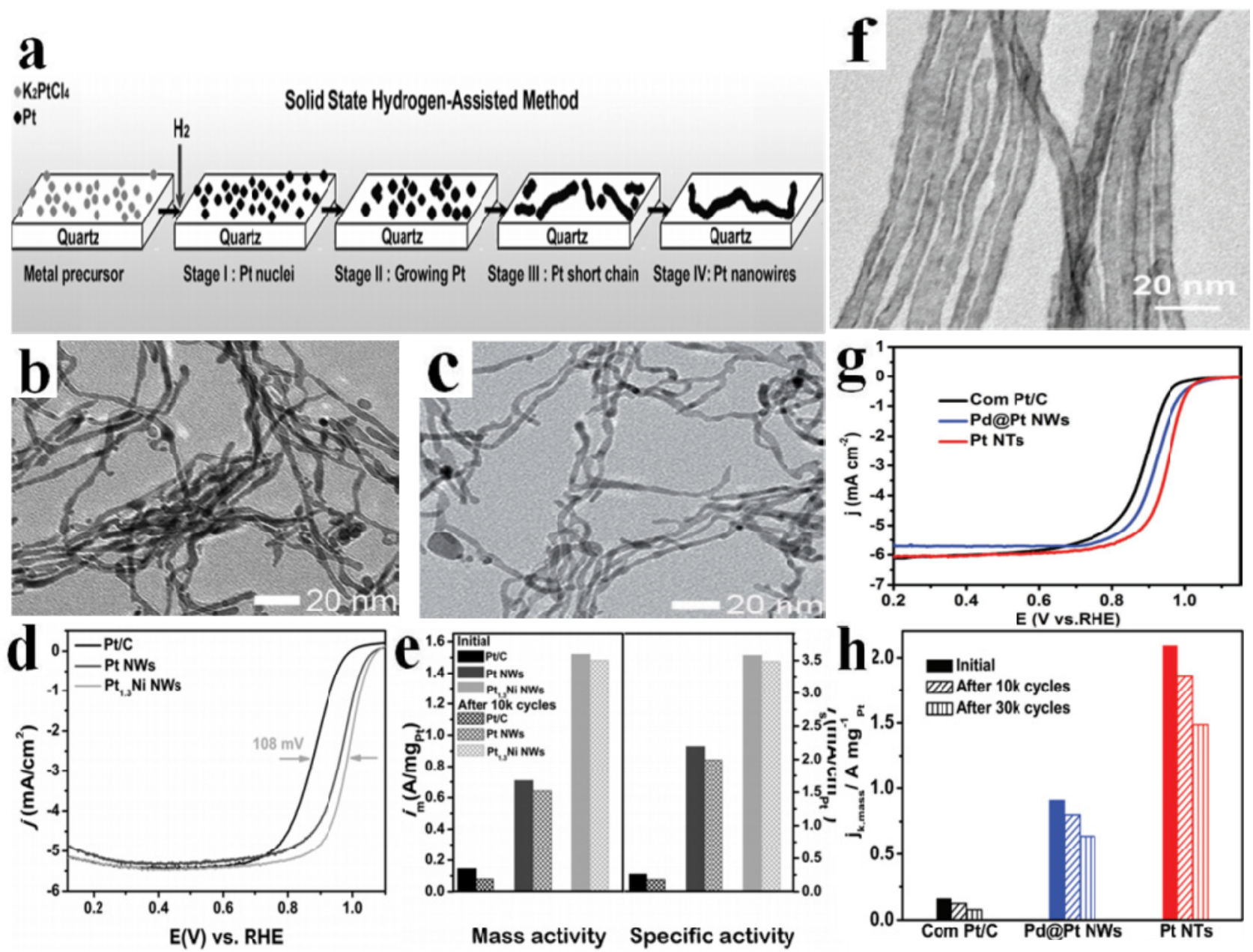

Fig. 3. (a) Schematic of the formation of free-standing ultrathin Pt NWs through the solid-state $\mathrm{H}_{2}$-assisted method. (b, c) Morphology and structure of $\mathrm{Pt}$ NWs and $\mathrm{Pt}_{1.3} \mathrm{Ni}$-alloy NWs. (d) ORR polarization curves with currents normalized to the geometric area of the rotating disk electrode. (e) Comparison of the area-specific activity and the mass-specific activity at $0.9 \mathrm{~V}$ vs. RHE before and after 10000 cycles. (f) High-magnification TEM images of Pt NTs. (g) ORR polarization curves of different catalysts. (h) A bar diagram showing a comparison of the mass activities of different materials for the ORR before and after 10000 and after 30000 cycles. Reproduced from Refs. [34, 35] with permission from Wiley-VCH.

from the incorporation of the heteroatom for optimizing the adsorption/desorption energy of the hydroxyl group, which is important for the catalytic performance.

\subsubsection{D non-Pt-based nanostructures for the ORR}

Apart from the Pt-based materials, non-Pt-metal compounds are a class of promising materials that can substitute $\mathrm{Pt}$ as ORR electrocatalysts, and include transition metal catalysts and even carbon materials [42-46]. Recently, numerous efforts have been made to improve the catalytic activities of 1D non-Pt metal nanostructures for the ORR. The materials investigated include transition metals, such as $\mathrm{Pd}, \mathrm{Ag}$, Co, and $\mathrm{Mn}$, or their alloy nanostructures [47-53]. As a promising alternative, Pd has received much attention because it is an excellent catalyst for the ORR. Recently, Xia and coworkers developed a method to synthesize penta-twinned Pd NWs with diameter of about 8 $\mathrm{nm}$ in one pot (Fig. 4(a)). The axis of the as-synthesized Pd NWs grows along the [110] direction. The distinctive structural characteristics and the unique morphology can optimize the inner electronic structure and thus significantly boost the ac- tivity for the ORR in $0.1 \mathrm{M}$ aqueous $\mathrm{KOH}$ solution. The prepared Pd NWs exhibit greater ORR activity than Pt/C, and the mass activity and specific activity are 2-3 times higher than those of the Pt/C (Fig. 4(b)). The superior ORR catalytic activity can be mainly ascribed to the unique structural characteristics. The special 1D morphology, with an ultrathin diameter and a surface strain, can optimize the absorption and desorption energies of $\mathrm{O}_{2}$ and thus enhance the ORR activity. In addition to Pd, as a relatively abundant, inexpensive (about 50 times cheaper than Pt), and highly conductive metal, Ag is another good alternative for an efficient ORR catalyst. In general, metals with weaker interactions with oxygen are less active than Pt and the $\mathrm{O}-\mathrm{O}$ bond cleavage is less favorable on Ag. On the other hand, the rate of the initial $\mathrm{OOH}$ formation step determines the overall reaction rate on $\mathrm{Ag}$, and a pure $\mathrm{Ag}$ catalyst exhibits inferior ORR characteristics than the Pt-based counterparts. Doping Ag with a heteroatom can regulate the surface strain and change the bonding energy between $\mathrm{O}_{2}$ and the catalytic sites, which has been proved to be a good method for boosting the ORR catalytic activity and stability of Ag. The related studies testified 

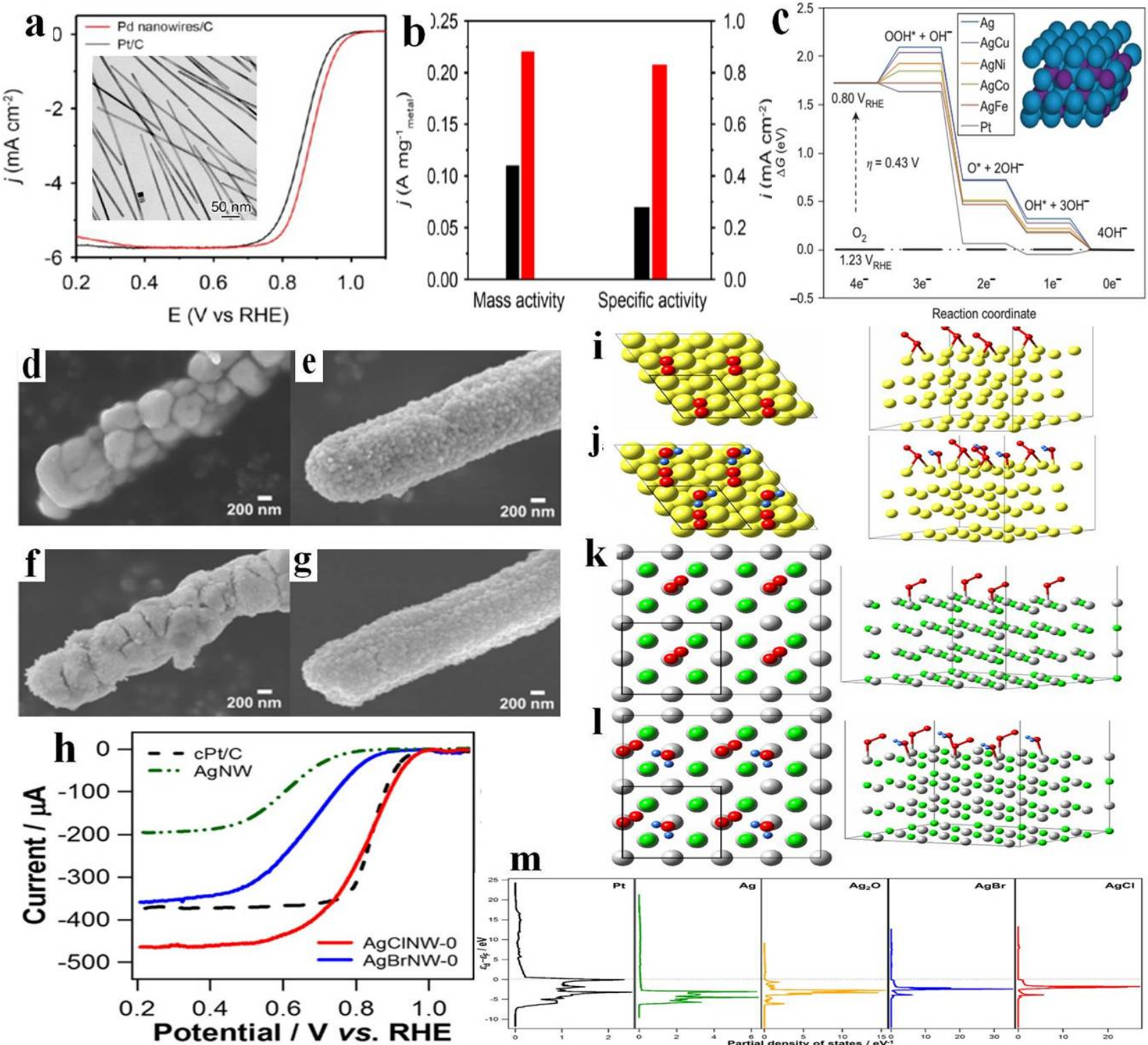

Fig. 4. (a) Positive-going ORR polarization curves of Pd NWs/C and commercial Pt/C. The inset shows a TEM image of the Pd NWs. (b) Mass and specific activities of the Pd NW/C and commercial Pt/C at 0.9 V vs. RHE. Reproduced from Ref. [57] with permission from the American Chemical Society. (c) DFT-calculated free-energy diagram for the ORR on alloy catalyst surfaces. Reproduced from Ref. [51] with permission from Nature. FE-SEM images of (d) AgCl NW-0, (e) AgCl NW-P, (f) AgBr NW-0, and (g) AgBr NW-P. (h) RDE voltammograms for the ORR on Ag NWs, AgCl NW-0, AgBr NW-0, and $\mathrm{Pt} / \mathrm{C}$ obtained at $1600 \mathrm{rpm}$. Illustration of $\mathrm{O}_{2}$ adsorption on (i) Pt (111), (j) $\mathrm{H}_{2} \mathrm{O}$-adsorbed $\mathrm{Pt}(111),(\mathrm{k}) \mathrm{AgCl}(100)$, and (l) $\mathrm{H}_{2} \mathrm{O}$-adsorbed AgCl (100) surfaces. The $\mathrm{Ag}, \mathrm{Cl}, \mathrm{Pt}, \mathrm{O}$, and $\mathrm{H}$ atoms are colored gray, green, yellow, red, and blue, respectively. (m) Electronic density of states projected onto the d-band for different metal reciprocal cells $\left(\varepsilon_{\mathrm{d}}-\varepsilon_{\mathrm{F}}\right.$; relative to the Fermi level). Reproduced from Ref. [50] with permission from Elsevier.

that Ag $3 d$ metal alloys, particular those formed with Co, can change the reactivity of Ag for the ORR via the ligand effect or a synergistic effect $[49,54,55]$. Linic and coworkers in 2014 designed low-cost AgCo alloy nanoparticles for oxygen reduction [51]. The authors studied the elementary reaction energy of the ORR based on the DFT. As shown in Fig. 4(c), compared with the pure Ag electrocatalyst, a more active Ag-based catalyst can bind an $\mathrm{O}$-containing species $(\mathrm{OOH}$ or $\mathrm{OH})$ more strongly, but not to the extent that subsequent removal is difficult, which promotes the rate-limiting reaction.

Compared with AgCo nanoparticles, Lee and coworkers reported a type of bimetallic AgCo nanotubes as ORR catalysts
[56]. Electrochemical studies showed that the AgCo nanotubes are superior to simple Co nanotubes, Ag NWs, and pure Pt for the ORR. Furthermore, Ag-nonmetal hybrid nanomaterials also exhibited potential for application in catalysts. Lee et al. [50] synthesized two types of $\mathrm{Ag}$ halide NWs, $\mathrm{AgCl}$ NWs and $\mathrm{AgBr}$ NWs, through the galvanic replacement reaction between a halide precursor and Ag NWs. After the galvanic replacement reaction, the smooth surface and pentagonal cross-section of the Ag NWs changed into rough surfaces with many large particles (Fig. 4(d)-(g)). Electrocatalytic measurements in alkaline media revealed that AgCl NW-0 (without PVP) exhibits the best ORR property in terms of limiting current $(-460.8 \mu \mathrm{A})$ and on- 
Table 1

Comparison of the ORR performances of various one-dimensional nanostructured materials.

\begin{tabular}{lccccc}
\hline Catalyst & $\begin{array}{c}\text { ECSA } \\
\left(\mathrm{m}^{2} / \mathrm{g}\right)\end{array}$ & $\begin{array}{c}\text { Mass activity } \\
@ 0.9 \mathrm{~V} \\
\left(\mathrm{~A} / \mathrm{mg}_{\mathrm{pt}}\right)\end{array}$ & $\begin{array}{c}\text { Specific } \\
\text { activity } \\
\left(\mathrm{mA} / \mathrm{cm}^{2}\right)\end{array}$ & $\begin{array}{c}\text { Stability } \\
\text { test } \\
(\text { cycles })\end{array}$ & Ref. \\
\hline Pt/Ag-Pd NTs & 50.5 & 0.377 & 1.53 & 5000 & {$[29]$} \\
PtNi NWs & 43.4 & 4.15 & 9.20 & 10000 & {$[30]$} \\
PtNiCo NWs & 82.2 & 4.20 & 5.11 & 30000 & {$[32]$} \\
$\mathrm{Pt}_{3}$ Ni NWs & 66.8 & 5.6 & - & 20000 & {$[33]$} \\
Pt NWs & 32.3 & 0.71 & 2.20 & 10000 & {$[34]$} \\
Pt 1.3 Ni NWs & 42.5 & 1.52 & 3.58 & 10000 & {$[34]$} \\
Pt NTs & 91.4 & 2.09 & 2.28 & 30000 & {$[35]$} \\
Pd@Pt NWs & 48.6 & 0.91 & 1.87 & 30000 & {$[35]$} \\
Rh-doped Pt NWs & 86.4 & 1.41 & 1.63 & 10000 & {$[39]$} \\
Pt NW/SG & 24.5 & 0.17 & 0.68 & 3000 & {$[40]$} \\
PtCo NWs & 52.1 & 3.71 & 7.12 & 20000 & {$[41]$} \\
Pt Pd ${ }_{9} A u$ NWs & - & 2.54 & 0.98 & 30000 & {$[42]$} \\
Pd ${ }_{9}$ Au NWs & - & $0.64(\mathrm{Pd})$ & 0.45 & 30000 & {$[42]$} \\
\hline
\end{tabular}

set potential (1.01 V vs. RHE), which are even better than those of commercial Pt/C (Fig. 4(h)). Moreover, the DFT calculations elucidated the interrelation between the surface structure of the catalyst, adsorption of $\mathrm{O}_{2}$ molecules, and the related ORR products (Fig. 4(i)-(1)). First, the authors calculated the relationship between the d-band center energy and the Fermi level $\left(\varepsilon_{\mathrm{d}}-\varepsilon_{\mathrm{F}}\right)$ of the metal to determine the reactivity. Electronegativity $(\mathrm{O}>\mathrm{Cl}>\mathrm{Br})$ is an important impact index, and the density of states and $\varepsilon_{\mathrm{d}}$ of $\mathrm{Ag}$ are upshifted by a great degree in the order of $\mathrm{Ag}<\mathrm{Ag}_{2} \mathrm{O}<\mathrm{AgBr}<\mathrm{AgCl}<\mathrm{Pt}$ (Fig. 4(m)). The abnormal position of $\mathrm{Ag}_{2} \mathrm{O}$ in the order could be attributed to the $\mathrm{O}$ shared by the two $\mathrm{Ag}$ atoms in $\mathrm{Ag}_{2} \mathrm{O}$. Secondly, it was found that during the reaction, $\mathrm{O}_{2}$ molecules are adsorbed on different sites through two different modes: bridged adsorption on Pt (111) sites and adsorption on $\mathrm{AgCl}(100)$ at the $\mathrm{Ag}$ atom sites. The oxygen adsorption energy and $0-0$ bond length $\left(d_{0-0} / \AA\right)$ were calculated to be as follows: on bare Pt, $0.7347 \mathrm{eV}, 1.354 \AA$; $\mathrm{H}_{2} \mathrm{O}$-adsorbed Pt (111), $0.7551 \mathrm{eV}, 1.348 \AA$, AgCl (100), 0.2331 $\mathrm{eV}, 1.293 \AA$, and $\mathrm{H}_{2} \mathrm{O}$-adsorbed $\mathrm{AgCl}$ (100) surface, $0.7645 \mathrm{eV}$, $1.307 \AA$. It is obvious that the adsorption energy $\left(-E_{\mathrm{ad}}, \mathrm{O}_{2}\right)$ and O-O bond length of the $\mathrm{O}_{2}$ molecules adsorbed on $\mathrm{AgCl}(100)$ are smaller than those of the $\mathrm{O}_{2}$ adsorbed on the commercial $\mathrm{Pt} / \mathrm{C}$, resulting in a superior catalytic performance.

In recent years, both enhanced activity and enhanced stability of 1D metal nanostructures for the ORR have been realized. The developed NWs or nanotubes exhibited superior catalytic properties-excellent activity compared to $\mathrm{Pt} / \mathrm{C}$ and superb stability over a thousand cycles. However, there are still several challenges that need to be addressed when the catalysts are used in membrane electrode assemblies (MEA). (1) Catalysts can be only obtained in small-scale experiments with low productions or poor repeatabilities; (2) the harsher terms in the MEA place higher demands on the activity and stability of the catalyst. Hence, future research should pay more attention on improving the productivity, leading to the realization of industrial catalysts with improved performance in severe reaction conditions for the real-time application of 1D metal nanocata- lysts.

\subsection{D nanostructured catalysts for the MOR}

A DMFC is a clean power device that is used in portable mini electrical applications. DMFCs have many advantages, such as high energy density, high efficiency, and low pollution [58-60]. On the anode side of the MEA, methanol, as the fuel, reacts with water to transform into carbon dioxide, protons, and electrons, along with the release of chemical energy. The reaction can be described as

$$
\mathrm{CH}_{3} \mathrm{OH}+\mathrm{H}_{2} \mathrm{O} \rightarrow \mathrm{CO}_{2}+6 \mathrm{H}^{+}+6 \mathrm{e}^{-}
$$

However, this reaction exhibits sluggish kinetics even on a Pt surface, which significantly reduces the fuel efficiency. The reaction mechanism of methanol electrooxidation on Pt catalysts has been studied for years and it has been well accepted that it involves three parallel oxidation pathways: complete oxidation into $\mathrm{CO}_{2}$ (C1 pathway), and partial oxidation-incomplete oxidation into $\mathrm{HCHO}$ or $\mathrm{HCOOH}$ (C2, C3 pathways) [61-63]. It is worth noticing that the three pathways may occur simultaneously and therefore highly selective catalysts are needed to control the nature of the final product. The detailed reaction mechanism and pathways are illustrated in Fig. 5. The $\mathrm{C} 1$ pathway, with $6 \mathrm{e}^{-}$transfer, results in the production of $\mathrm{CO}_{2}, \mathrm{CO}_{3}{ }^{2-}$, or $\mathrm{HCO}_{3}{ }^{-}$, depending on the nature of the medium used. For the $\mathrm{C} 2$ or C3 pathway, methanol is incompletely electrooxidized to formaldehyde or formic acid, with $2 \mathrm{e}^{-}$ or $4 \mathrm{e}^{-}$transfer, and then further oxidized into $\mathrm{CO}_{2}$.

These three pathways could be further divided into two steps: (1) gradual dehydrogenation of methanol, and (2) further oxidation of the carbon-containing species. It has also been revealed that different types of defects in the electrocatalysts play different roles in the MOR [64]. Therefore, the composition, electronic structure, and morphology of the catalysts have a certain influence on the selection of the reaction pathway and the efficiency of methanol oxidation.

\subsubsection{D Pt-based nanostructures for the MOR}

In the case of anode catalysts, the current efforts mainly focus on improving the performance and reducing the cost. Until now, Pt-based metal nanomaterials have been indispensable as MOR catalysts [65-68]. Wang and coworkers [19] adopted a facile solvothermal method to synthesize Pt NWs with $3 \mathrm{~nm}$ in diameter. The NWs grew along the [111] direction, with many exposed high-index facets and step structures. Such a crystal surface is beneficial for methanol dehydrogenation because the step-type adsorption sites are highly active. The HRTEM image also shows lattice fringes, with an interplanar spacing of about

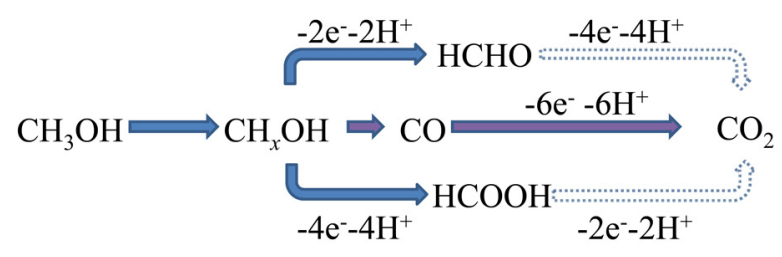

Fig. 5. Schematic illustration of the methanol oxidation pathways. 
$0.227 \mathrm{~nm}$, which matches well with that of the Pt (111) planes. The NWs exhibited higher mass and specific activities than commercial $\mathrm{Pt} / \mathrm{C}$ in an acidic medium. The outstanding electrocatalytic performance can be ascribed to the unique anisotropic structure of the 1D NWs, including their high stability, good crystallinity, high surface area, and large porosity with an interconnected network structure. However, some poisonous intermediates like CO could be firmly adsorbed onto the Pt-Pt interface, resulting in the poisoning of the partially active sites and a serious degradation of the catalytic performance. Many studies, including experiments and DFT calculations, have illustrated that the $\mathrm{CO}$ poisoning has a severely negative effect on methanol oxidation, and have put forward the possible $\mathrm{CO}$ poisoning route. During the methanol oxidation, the CO generated is first adsorbed on the Pt atom sites to form Pt-COads, and is then further oxidized into $\mathrm{CO}_{2}$ at high overpotentials [69-71]. Therefore, if $\mathrm{CO}$ is strongly adsorbed on the Pt atom sites, it can hardly be further oxidized, resulting in greater consumption of energy. Hence, adsorbed $\mathrm{CO}$ has been recognized as a poisoning intermediate, as it can block the further oxidation of methanol on a catalyst surface. One effective method to reduce the CO poisoning and minimize the usage of $\mathrm{Pt}$ is to prepare Pt alloys with other metals, especially earth-abundant transition metals. After regulating and controlling the composition and tuning the surface electronic structure, 1D Pt-based alloys with large surface areas, high electronic conductivities, rich surface defects, and quantum effects have become a class of promising materials [72-74]. For example, bimetallic PtRu nanomaterial electrocatalysts display excellent resistance to $\mathrm{CO}$ poisoning. In a $\mathrm{PtRu}$ alloy, Ru interacts with Pt and tends to offer the adsorbed hydroxyl groups $\left(\mathrm{OH}_{\mathrm{ads}}\right)$ at a relatively lower potential compared to pure Pt, which act as an oxidant to get rid of the poisoning species adsorbed on Pt [75]. The reactions are as follows:

$$
\begin{gathered}
\mathrm{Ru}+\mathrm{H}_{2} \mathrm{O} \rightarrow \mathrm{Ru}-\mathrm{OH}_{\mathrm{ads}}+\mathrm{H}^{+}+\mathrm{e}^{-} \\
\mathrm{Ru}-\mathrm{OH}_{\mathrm{ads}}+\mathrm{Pt}-\mathrm{CO}_{\mathrm{ads}} \rightarrow \mathrm{Ru}+\mathrm{Pt}+\mathrm{CO}_{2}+\mathrm{H}^{+}+\mathrm{e}^{-}
\end{gathered}
$$

In fact, as shown in Fig. 6(a)-(d), previous DFT calculations illustrated that only those atoms that are close enough $(\leq 4.0 \AA)$, i.e., the adsorbed $\mathrm{Pt}-\mathrm{CO}_{\text {ads }}$ and $\mathrm{Ru}-\mathrm{OH}_{\text {ads }}$ species, are able to interact to form Pt-CO-OH-Ru, and that there is no influence between the $\mathrm{OH}_{\text {ads }}$ and $\mathrm{CO}_{\text {ads }}$ species [76]. Thus, the alloying structure of PtRu materials with near-distance connection between the Pt and $\mathrm{Ru}$ atoms has more merits than the core-shell and heterostructured counterparts.

Dong and coworkers synthesized highly anisotropic PtRu NWs (Fig. 6(e)) [77]. These PtRu NWs exhibited a much higher MOR activity than $\mathrm{Pt} / \mathrm{C}$ in $0.1 \mathrm{M} \mathrm{HClO}_{4}$ with $0.5 \mathrm{M} \mathrm{CH}_{3} \mathrm{OH}$ (Fig. 6(f)). The XPS results (Fig. $6(\mathrm{~g})$ and (h)) indicate that the higher electronegativity of Pt can change the charge distribution and result in partial charge transfer from $\mathrm{Ru}$ to $\mathrm{Pt}$, which then changes the adsorption energies of $\mathrm{CO}_{\text {ads }}$ and $\mathrm{OH}_{\text {ads }}$ on Pt and $\mathrm{Ru}$. Additionally, compared to PtRu [100], the two adsorption
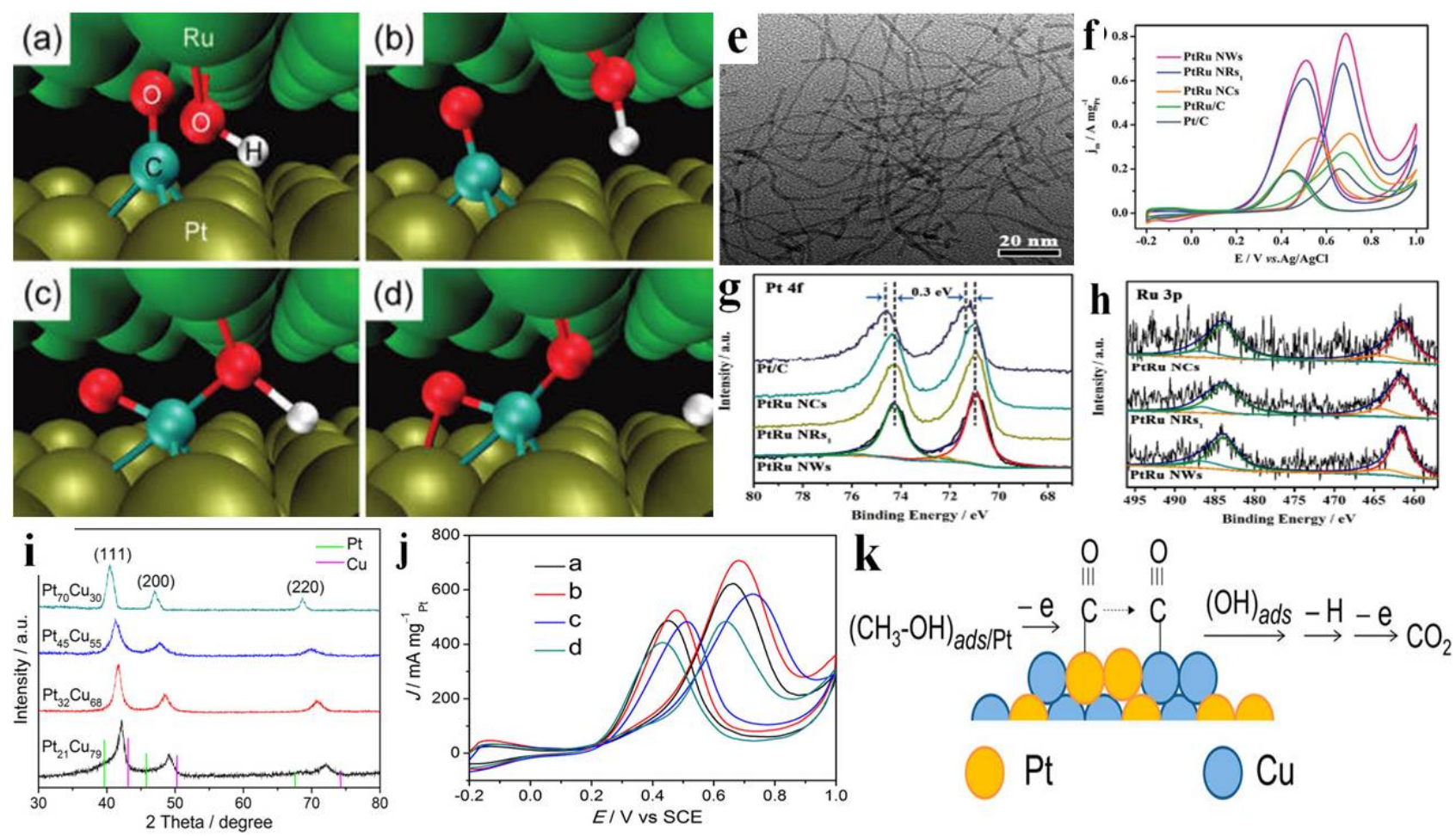

Fig. 6. Results of DFT simulations as functions of separation of Ru and Pt surfaces with adsorbed OH and CO, respectively, in close proximity. (a) A representative initial state of the molecular dynamic process, with the adsorbents located at the nearest energy-favorable positions. (b) When the distance between the surfaces is $4.5 \AA$, the calculation converges to a state in which $\mathrm{OH}_{\text {ads }}$ and $\mathrm{CO}_{\text {ads }}$ are further separated. (c) When the distance between the surfaces is reduced to $4.0 \AA, \mathrm{OH}_{\mathrm{ads}}$ and $\mathrm{CO}_{\mathrm{ads}}$ start to interact and form a transition state. (d) Subsequent convergence of panel c, resulting in the dissociation of the $\mathrm{O}-\mathrm{H}$ bond. (e) TEM image of PtRu NWs. (f) MOR catalytic performance. XPS patterns of the (g) Pt $4 f$ region and (h) Ru $3 p$ region (i) XRD patterns of the as-prepared $\mathrm{Pt}_{70} \mathrm{Cu}_{30}, \mathrm{Pt}_{45} \mathrm{Cu}_{55}, \mathrm{Pt}_{32} \mathrm{Cu}_{68}$, and $\mathrm{Pt}_{21} \mathrm{Cu}_{79} \mathrm{NWs}$. (j) $\mathrm{CV}$ curves of the $\mathrm{MOR}$ on (a) $\mathrm{Pt}_{45} \mathrm{Cu}_{55}$; (b) $\mathrm{Pt}_{32} \mathrm{Cu}_{68}$; (c) $\mathrm{Pt}_{21} \mathrm{Cu}_{79}$; and (d) Pt NWs. (k) The surface process of the MOR over PtCu NW catalyst. Reproduced from Ref. [76-78] with permission from the American Chemical Society. 
energies on PtRu [111] are much closer to the optimal values. Therefore, the PtRu [100] facet has inferior methanol oxidation activity and anti-CO-poisoning capacity compared to the [111] facet. However, the composition of the PtRu NW catalyst may reveal some changes under the DMFC operating conditions, because the $\mathrm{Ru}$ atom is easy to be depredated. It is desired to develop mature methods for controlling and maintaining the atomic ratio precisely and effectively. However, the cost of PtRu catalysts is still too high to be widely used in real applications. Fortunately, the properties of many other Pt-metal catalysts developed exceed that of the PtRu catalyst in terms of activity [79-83]. Zhong and coworkers [78] prepared ultrathin PtCu alloy NWs with different compositions. $\mathrm{Pt}_{32} \mathrm{Cu}_{68}$ alloy NWs were determined to have the optimal atomic ratio for methanol oxidation. Two $\mathrm{Cu}$ atoms surrounding one Pt atom in the catalyst result in an ensemble effect and a ligand effect, which contribute to the significantly improved electrocatalytic activity. The number of $\mathrm{Cu}$ atoms has an effect on the electronic structure and activity area of the alloy (Fig. 6(i) and (j)). For the MOR, the adsorption of methanol molecules on Pt sites, followed by dehydrogenation, occurs first. Then, the adsorption of the intermediate species $\left(\mathrm{CO}_{\mathrm{ad}}\right)$ on the catalytic sites can result in a decrease in the catalytic activity. The $\mathrm{CO}_{\mathrm{ad}}$ species may transfer from the $\mathrm{Pt}$ sites to the $\mathrm{Cu}$ sites to form $\mathrm{Cu}-\mathrm{CO}_{\mathrm{ad}}$ and the surface interactions of $\mathrm{Pt}-\mathrm{CO}_{\mathrm{ad}}+\mathrm{Cu}-\mathrm{OH}_{\mathrm{ad}}$ or $\mathrm{Cu}-\mathrm{CO}_{\mathrm{ad}}+$ $\mathrm{Cu}-\mathrm{OH}_{\text {ad }}$ can yield $\mathrm{CO}_{2}$ (Fig. 6(k))

\subsubsection{D non-Pt-based nanostructures for the MOR}

Despite the considerable improvements in the tolerance to CO-poisoning and the catalytic activity of Pt-based metal nanomaterials, DMFCs suffer from an unavoidable disadvantage: the high cost of the noble Pt and the low utilization. Hence, further research is required to develop more effective catalysts in terms of cost, activity, and stability. It is highly necessary to design Pt-free electrocatalysts having high activity and long life for the MOR. As far as we know, designing and synthesizing 1D non-noble metal materials with high MOR catalytic activities is still a challenge.

Several non-Pt materials have been reported to exhibit catalytic activities for the MOR [87-90]. Among the diverse Pt-free transition metal catalysts, $\mathrm{Ni}$ is considered to be a great alternative. Cheng and coworkers [86] adopted a facile one-pot strategy to prepare unique $\mathrm{Cu} / \mathrm{NiCu}$ core-shell alloy NWs (Fig. 7(a)). As shown in Fig. 7(b) and (d), the NW is composed of a $\mathrm{Cu}$ core and a NiCu alloy shell. The $\mathrm{Cu}$ core can greatly increase the surface charge transfer of the NWs. Meanwhile, the $\mathrm{NiCu}$ alloying shell can affect the entire distribution of electrons between the $\mathrm{Ni}$ and $\mathrm{Cu}$ atoms, and the synergistic effect can enhance the electrocatalytic performance. Furthermore, the core-shell structure can maximize the utilization of $\mathrm{Cu}$ and $\mathrm{Ni}$. The current density of the MOR on $\mathrm{Cu} / \mathrm{NiCu} \mathrm{NWs}$ is 34.9 $\mathrm{mA} / \mathrm{cm}^{2}$, which is 9 and 2 times higher than those on $\mathrm{Cu} \mathrm{NW} / \mathrm{C}$ and NiCu NPs, as shown in Fig. 7(e). The electrocatalytic mechanism of methanol oxidation on $\mathrm{Cu} / \mathrm{NiCu} \mathrm{NWs}$ can be formulated as follows (Fig. 7 (c)):

$$
\mathrm{Ni}(\mathrm{OH})_{2}+\mathrm{OH}^{-} \rightarrow \mathrm{NiOOH}+\mathrm{H}_{2} \mathrm{O}+\mathrm{e}^{-}
$$$$
\mathrm{NiOOH}+\mathrm{CH}_{3} \mathrm{OH} \rightarrow \mathrm{Ni}(\mathrm{OH})_{2}+\text { products }
$$

During multiple $\mathrm{CV}$ scanning in an alkaline medium, the $\mathrm{Ni}$ in the catalyst is activated to form a $\mathrm{NiOOH}$ layer and, therefore, an alkaline solution is necessary for Ni-based catalysts to be activated. Meanwhile, the reaction mechanism still remains unclear for other transition metals, though they may be similar to that for Ni. It should be noted that although the catalytic properties of some non-noble metal catalysts are comparable to those of Pt-based catalysts, the poor quality of the ion exchange membrane in the alkaline medium still limits their widespread application.

Recently developed non-noble metal catalysts show significantly enhanced MOR performances, which increases their prospects for actual commercial applications. It should be
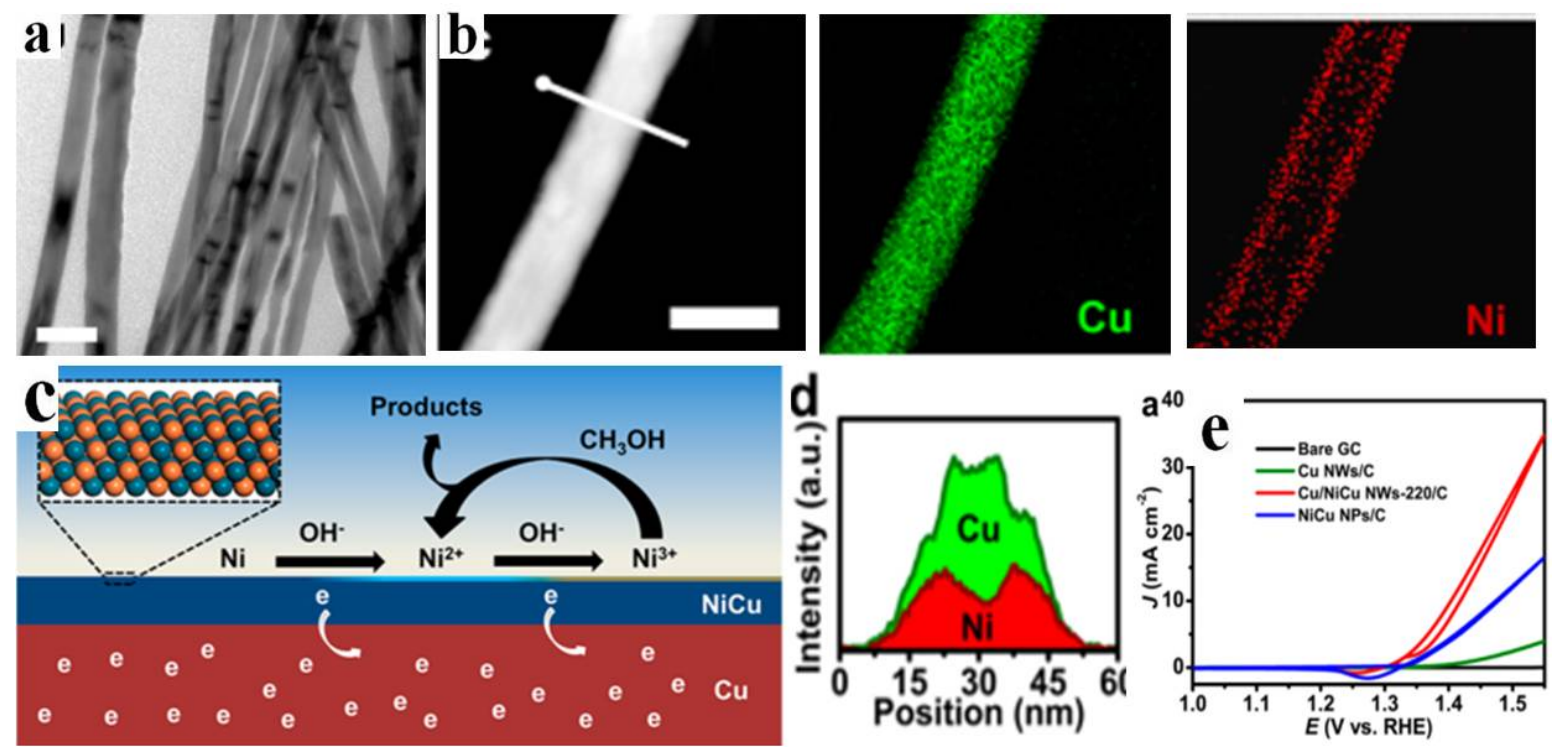

Fig. 7. (a) TEM image of $\mathrm{Cu} / \mathrm{NiCu}$ NWs, scale bar: $50 \mathrm{~nm}$. (b) HAADF-STEM image and the corresponding elemental mapping images for the $\mathrm{Ni}$ and $\mathrm{Cu}$ of the $\mathrm{Cu} / \mathrm{NiCu}$ NWs. (c) Mechanism of the MOR on the surface of $\mathrm{Cu} / \mathrm{NiCu}$ NWs. (d) EDS line profiles of the Cu/NiCu NWs. (e) CVs of four different catalysts in $1 \mathrm{M} \mathrm{KOH}$ electrolyte with $1 \mathrm{M}$ methanol. Reproduced from Ref. [86] with permission from the American Chemical Society. 
Table 2

Comparison of the MOR performances of various one-dimensional nanostructured materials.

\begin{tabular}{|c|c|c|c|c|c|}
\hline Catalyst & $\operatorname{ECSA}\left(\mathrm{m}^{2} / \mathrm{g}\right)$ & Peak potential/Onset potential (V) & $\mathrm{SA} / \mathrm{MA}\left(\mathrm{mA} / \mathrm{cm}^{2}\right) /\left(\mathrm{A} / \mathrm{mg}_{\mathrm{Pt}}\right)$ & Stability test & Ref. \\
\hline Pt NTs & 23.9 & $0.86 /-$ & $1.62 /-$ & $5400 \mathrm{~s}$ & [65] \\
\hline FePtPd NWs & - & $0.61 /-$ & $-/ 0.49$ & $7200 \mathrm{~s}$ & [67] \\
\hline PtZn NWs & - & $-/ 0.29$ & $3.48 / 1.01$ & $1500 \mathrm{~s}$ & [68] \\
\hline $\mathrm{Pd}_{3} \mathrm{Pt}_{1} \mathrm{NWs}$ & - & $0.82 / 0.41$ & $9.91 /-$ & $3600 \mathrm{~s}$ & [74] \\
\hline PtRu NWs & 72.1 & $-/-$ & $1.16 / 0.82$ & $4000 \mathrm{~s}$ & [77] \\
\hline $\mathrm{Pt}_{32} \mathrm{Cu}_{68} \mathrm{NWs}$ & 70.2 & & $-/ 0.71$ & $3600 s$ & [78] \\
\hline PtPdCu 3DPA & 49.8 & $-/-$ & $2.96 / 1.51$ & $7200 \mathrm{~s}$ & [79] \\
\hline $\mathrm{CuPt}_{3}$ wavy NWs & 20.3 & $-/-$ & $2.80 / 0.64$ & $3000 \mathrm{~s}$ & [80] \\
\hline PtRuFe NWs & - & $-/ 0.44$ & $1.10 /-$ & $3600 \mathrm{~s}$ & [81] \\
\hline $\mathrm{PtCu}_{2.1} \mathrm{NWs}$ & 46.9 & $-/-$ & $3.31 / 1.56$ & 1000 cycles & [84] \\
\hline PtFe NWs & 65.6 & $-1-$ & $1.20 /-$ & 1000 cycles & [85] \\
\hline PtCo NWs & 81.1 & $-/-$ & $1.07 /-$ & 1000 cycles & [85] \\
\hline PtNi NWs & 61.2 & $-1-$ & $1.34 /-$ & 1000 cycles & [85] \\
\hline PtCu NWs & 71.4 & $-1-$ & $1.26 /-$ & 1000 cycles & [85] \\
\hline $\mathrm{Cu} / \mathrm{NiCu}$ NWs & _- & $-1-$ & $34.9 / 0.87\left(\mathrm{~A} / \mathrm{mg}_{\text {metal }}\right)$ & $10000 \mathrm{~s}$ & [86] \\
\hline
\end{tabular}

SA: special activity; MA: mass activity.

pointed out that although great progress has been made on anode catalysts in terms of the design, preparation, and application, much work still needs to be carried out in order to overcome the following challenges: (1) Severe performance degradation caused by the dissolution of transition metals during actual operation; (2) MEA has a detrimental influence on gas diffusion and proton transfer; and (3) The catalytic performance measured by using a three-electrode system in the lab may be much different from that observed in practical fuel cells. In summary, further research is still needed to design and develop low-cost high-performance non-Pt catalysts for large-scale practical applications.

\subsection{D nanostructured catalysts for the HER}

Economic hydrogen $\left(\mathrm{H}_{2}\right)$ production from WS can provide clean renewable energy, which could reduce the energy crisis brought about by the excessive consumption of fossil fuels [91-93]. Electrochemical HER is a half-reaction that comprises the WS reaction, which can be conducted over a wide $\mathrm{pH}$ range, from neutral, acidic, to alkaline media. In fact, the performance and actual application of HER catalysts are greatly limited in acidic media owing to the poor durability and an unsatisfactory membrane. Pt and Pt-based noble metal catalysts have been recognized as the most efficient for the HER, while non-noble transition metal catalysts have also displayed attractive HER catalytic performances. The HER occurs through the Volmer-Tafel or Volmer-Heyrovsky route [94,95].

In an acid medium:

$$
\begin{aligned}
& \text { Overall reaction: } 2 \mathrm{H}^{+}+2 \mathrm{e}^{-} \rightarrow \mathrm{H}_{2} \\
& \mathrm{H}_{3} \mathrm{O}^{+}+\mathrm{e}^{-} \rightarrow \mathrm{H}_{\text {ads }}+\mathrm{H}_{2} \mathrm{O} \text { (Volmer) } \\
& \mathrm{H}_{\text {ads }}+\mathrm{H}_{\text {ads }} \rightarrow \mathrm{H}_{2} \text { (Tafel) } \\
& \mathrm{H}_{3} \mathrm{O}^{+}+\mathrm{H}_{\text {ads }}+\mathrm{e}^{-} \rightarrow \mathrm{H}_{2}+\mathrm{H}_{2} \mathrm{O} \text { (Heyrovsky) }
\end{aligned}
$$

In an alkaline medium:

Overall reaction: $2 \mathrm{H}_{2} \mathrm{O}+2 \mathrm{e}^{-} \rightarrow \mathrm{H}_{2}+2 \mathrm{OH}^{-}$

$$
\mathrm{H}_{2} \mathrm{O}+\mathrm{e}^{-} \rightarrow \mathrm{H}_{\text {ads }}+\mathrm{OH}^{-} \text {(Volmer) }
$$$$
\mathrm{H}_{\text {ads }}+\mathrm{H}_{\mathrm{ads}} \rightarrow \mathrm{H}_{2} \text { (Tafel) }
$$

$\mathrm{H}_{2} \mathrm{O}+\mathrm{H}_{\text {ads }}+\mathrm{e}^{-} \rightarrow \mathrm{H}_{2}+\mathrm{OH}^{-}$(Heyrovsky)

Here, $\mathrm{H}_{\text {ads }}$ represents surface-adsorbed $\mathrm{H}$. The binding of hydrogen onto the electrode is considered as the rate-limiting step, which is dependent on the intrinsic conductivity and active sites of the electrocatalysts. If the desorption of $\mathrm{H}_{\mathrm{ads}}$ is fast, the rate-determining step is the Tafel (Tafel slope is about 30 $\mathrm{mV} / \mathrm{dec}$ )/Heyrovsky reaction (about $40 \mathrm{mV} / \mathrm{dec}$ ) or the Volmer process with a Tafel slope of $120 \mathrm{mV} /$ dec. Several important strategies need to be adopted in the design of novel HER catalysts: (1) Optimizing the adsorption-desorption Gibbs free energies of the reactants to avoid the Volmer process as part of the overall reaction; (2) Increasing the conductivity of the catalyst in order to boost charge transfer; and (3) Enhancing mass transfer to maximize the efficiency of the catalyst $[91,96]$.

\subsubsection{D Pt-based nanostructures for the HER}

Although Pt and Pt-based noble metal catalysts show the best catalytic activities for the HER, the reaction kinetics on $\mathrm{Pt}$ in alkaline media is limited by the water-dissociation rate, which can be hundreds of times smaller than that in an acid $[97,98]$. In alkaline solutions, as described by equation 17 , water dissociation occurs first, and then, the $\mathrm{H}_{\text {ads }}$ recombines into $\mathrm{H}_{2}$ molecules. The first step requires significant energy for splitting water into $\mathrm{H}_{\text {ads. }}$ Therefore, designing functional groups that are efficient in cleaving the $\mathrm{H}-\mathrm{OH}$ bonds of water may be helpful for the dissociation step and can accelerate the overall reaction. Recently, various Pt-based nanostructures have been studied as HER catalysts in alkaline media [99]. Huang and coworkers [100] designed four types of PtNi NW/C, in which the shell is Pt-rich in and the inner region is Ni-rich. After annealing in air, a filmy $\mathrm{NiO}_{x}$ shell can be formed outside the $\mathrm{Pt}_{3} \mathrm{Ni}_{3} \mathrm{NW} / \mathrm{C}$ surface and $\mathrm{Pt}$ is concentrated in the interior. Therefore, the pristine $\mathrm{Pt}_{3} \mathrm{Ni}_{3} \mathrm{NWs}$ are converted into novel $\mathrm{NiO}_{x} / \mathrm{Pt}_{3} \mathrm{Ni}$ heterostructures. The nanostructures showed the following order with respect to the HER activity: $\mathrm{Pt}_{3} \mathrm{Ni}_{4}$ NWs/C-air $<\mathrm{Pt}_{3} \mathrm{Ni}_{1}$ NWs/C-air $<\mathrm{Pt}_{3} \mathrm{Ni}_{2}$ NWs/C-air $<\mathrm{Pt}_{3} \mathrm{Ni}_{3}$ 
NWs/C-air. The formed $\mathrm{Pt}_{3} \mathrm{Ni}_{3}$ NWs/C-air exhibited an extremely low overpotential in $1 \mathrm{M} \mathrm{KOH}\left(\eta_{10}=40 \mathrm{mV}\right.$ at 10 $\mathrm{mA} / \mathrm{cm}^{2}$ ). The high activity was attributed to the existence of a $\mathrm{NiO}_{x} / \mathrm{Pt}_{3} \mathrm{Ni}$ interface. The $\mathrm{NiO}_{x}$ on the surface of the catalyst could boost the water dissociation and the electrostatic affinity with the offspring $\mathrm{OH}^{-}$. The vacant $\mathrm{Pt}$ sites close to the $\mathrm{NiO}_{\mathrm{x}}$ would adsorb $\mathrm{H}_{\text {ads }}$ to quickly generate $\mathrm{H}_{2}$ molecules, and such a synergistic effect can finally enhance the HER in alkaline media. Besides, by taking advantage of the PtNi NWs, the authors developed another class of $\mathrm{Pt}_{3} \mathrm{Ni}_{x} / \mathrm{NiS}$ metal/sulfide heterostructures through a simple sulfuration process [101]. During sulfuration, the original structure of the Pt-Ni NWs was maintained, but NiS nanoparticles were formed on the surface at the same time (Fig. 8(a)-(d)). The synthesized $\mathrm{Pt}_{3} \mathrm{Ni}_{2}$ NWs-S/C, containing a high density of NiS-Pt ${ }_{3} \mathrm{Ni}$ interfaces, showed the highest HER activity among the samples (Fig. 8(e)), which is about ten times higher than that of commercial Pt/C. DFT calculations (Fig. 8(f) and (g)) revealed that the energy barriers of water dissociation on Pt [111] and NiS [100] surfaces are 0.89 and $0.32 \mathrm{eV}$, respectively, which suggest that breaking the $\mathrm{OH}-\mathrm{H}$ bond of water into $\mathrm{Hads}_{\mathrm{a}}$ and $\mathrm{OH}$ is easier on NiS [100] than on Pt [111]. In this heterostructure, the active NiS sites can adequately enhance the water dissociation, and $\mathrm{H}_{2}$ is generated from two close $\mathrm{H}_{\text {ads }}$ adsorbed on the Pt sites through the Tafel or Heyrovsky step. The $\mathrm{Pt}_{3} \mathrm{Ni}$ [111], NiS [100], and Pt [111] surfaces have different free hydrogen adsorption energies. The calculations revealed that the free energy $G_{\mathrm{H}^{*}}$ on the $\mathrm{Pt}_{3} \mathrm{Ni}$ [111] surface is much closer to the optimal value $\left(G_{\mathrm{H}^{*}}=0 \mathrm{eV}\right)$. However, the $G_{\mathrm{H}^{*}}$ is high on the NiS surface $\left(G_{\mathrm{H}^{*}}=0.56 \mathrm{eV}\right)$, which can severely suppress the desorption step of Hads. Therefore, it is the synergistic effect between $\mathrm{Pt}_{3} \mathrm{Ni}$ and $\mathrm{NiS}$ that largely increases the HER activity in alkaline media.

In another study, PtCo alloy nanomaterials were found to be capable of effectively accelerating the sluggish kinetics of the HER [103]. The LSV curves shown in Fig. 8(h) indicate that the PtCo alloy exhibits a superior activity for the HER than $\mathrm{PtO}_{2}$. The activity of PtCo for hydrogen adsorption and the conversion of $\mathrm{H}_{\text {ads }}$ into $\mathrm{H}_{2}$ is superior to that of Pt. The DFT calculation result reveals the different free energy barriers of PtCo [100], Pt [111], and Co [111] for the HER in an alkaline electrolyte. The $\Delta G_{\mathrm{H}^{*}}$ on a PtCo [100] surface is smaller than those on the original Pt [111] and Co [111] and is close to the optimal value $\left(\Delta G_{\mathrm{H}^{*}} \approx 0\right.$ ) (Fig. 8(i)). The strong electronic synergistic effect between the $\mathrm{Pt}$ and Co atoms can reduce the energy barrier of water desorption. In the PtCo structures, the Co species plays an active role in dissociating water and the PtCo atoms act as the active sites that are responsible for the adsorption of the

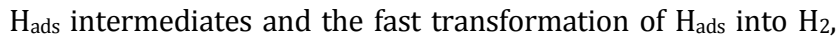
which enhances the HER performance. It is worth noting that the principle to increase the HER performance by using Pt-based metal nanostructures is similar. Pure Pt cannot effectively dissociate water into $\mathrm{H}_{\text {ads }}$ and $\mathrm{OH}$, and integration with the atoms of another transition metal can alter the entire electronic structure and the energy barriers associated with hydrogen adsorption and conversion on catalysts.

\subsubsection{D non-Pt-based nanostructures for the HER}

At present, Pt and Pt-based materials are the most efficient HER catalysts owing to their small overpotentials and Tafel slopes $[104,111,112]$. However, the high cost and the relative scarcity of noble metals greatly limit their widespread application for economically obtaining hydrogen through WS. Therefore, earth-abundant metals with efficient WS activities may be a good alternative to reduce the cost associated with actual use [113]. Among the earth-abundant non-noble metals, Ni- and Co-based metal nanomaterials with unique electronic properties and synergistic effects have become the focus point as electrocatalysts for the HER. For example, Sun's group developed CoP NWs with excellent HER activity and durability in an acidic solution [102]. The CoP NWs having a porous structure exhibited large surface areas and the Co and $\mathrm{P}$ are uniformly distributed over the NWs (Fig. 9(a) and (b)). It is amazing that the CoP NWs exhibited a small overpotential $\left(\eta_{10}=40 \mathrm{mV}\right)$ and a small Tafel slope (54 mV/dec) (Fig. 9(c) and (d)), which indicated that the reaction proceeds through the Volmer-Heyrovsky mechanism. Most importantly, the CoP NWs could survive the long durability test (of duration at least $50 \mathrm{~h}$ ) and the supercatalytic activity could be maintained during the long process. According to previous calculations [106], charge can be partially transferred from Co to $\mathrm{P}$ in Co-P covalent bonds, which can result in the metal center of Co $\left(\delta^{+}\right)$and the base $\mathrm{P}\left(\delta^{-}\right)$. The $\operatorname{Co}\left(\delta^{+}\right)$acts as a hydride-acceptor and the basic $\mathrm{P}\left(\delta^{+}\right)$functions as proton-acceptor centers to promote the HER activity. Subsequently, Hu's research group reported a unique $\mathrm{NiCo}_{2} \mathrm{P}_{\mathrm{x}}$ bimetallic phosphate NW catalyst (Fig. 9(e) and (f)) [107]. The NWs exhibited excellent HER activity and durability in pH-universal electrolytes (Fig. 9(g)-(i)), including an alkaline electrolyte (1 M KOH), a neutral solution (1 M PBS), and an acidic medium $\left(0.5 \mathrm{M} \mathrm{H}_{2} \mathrm{SO}_{4}\right)$. To be specific, the NWs only required 58, 63, and $104 \mathrm{mV}$ for the current density to reach 10 $\mathrm{mA} / \mathrm{cm}^{2}$ in $1 \mathrm{M} \mathrm{KOH}, 1 \mathrm{M} \mathrm{PBS}$, and $0.5 \mathrm{M} \mathrm{H}_{2} \mathrm{SO}_{4}$, respectively, which exceed those of Pt sheets in alkaline and neutral media. Such high-efficiency catalytic behavior can be attributed to the effective increase in the Volmer reaction by $\mathrm{NiCo}_{2} \mathrm{P}_{x}$. In addition, the $\mathrm{NiCo}_{2} \mathrm{P}_{x}$ also exhibited outstanding operational stability and durability; it could withstand $5000 \mathrm{CV}$ cycles or $30 \mathrm{~h}$ of the chronoamperometry test at high current densities. The reaction mechanism was also proposed (Fig. 9(j)). First, water enters the surface of $\mathrm{NiCo}_{2} \mathrm{P}_{x}$, and the $\mathrm{H}-\mathrm{OH}$ bond is weakened by the electronic effects produced from the interaction between the heteroatom metal centers $\left(\mathrm{M}^{\delta+}, \mathrm{M}=\mathrm{Ni}, \mathrm{Co}\right)$ and the heteroatom non-metal centers $\left(\mathrm{O}\right.$ atom, $\mathrm{P}$ atom $\left(\mathrm{P}^{\delta^{-}}\right)$, and $\mathrm{H}$ atom). Secondly, with the help of free electrons, water is dissociated into $\mathrm{OH}^{-}$and $\mathrm{H}$ atom, followed by the adsorption of $\mathrm{OH}^{-}$ on the $\mathrm{M}^{\delta+}$ of the surface, and the $\mathrm{H}$ atom is shifted to a vacant site to form $\mathrm{H}_{\mathrm{ads}}$ (Volmer reactions). Finally, the $\mathrm{H}_{\mathrm{ads}}$ recombines via the Tafel pathway or the Heyrovsky pathway to produce a $\mathrm{H}_{2}$ molecule, along with the desorption of $\mathrm{OH}^{-}$from the interface. For the $\mathrm{NiCo}_{2} \mathrm{P}_{x} \mathrm{NWs}$, the Ni sites are active for water dissociation, while the recombination of $\mathrm{H}_{\text {ads }}$ into $\mathrm{H}_{2}$ likely occurs on the surface Co sites in the form of a fast Heyrovsky or Tafel step. This type of synergistic effect from $\mathrm{NiCo}_{2} \mathrm{P}_{x}$ is similar to those observed in the abovementioned catalysts.

It has been accepted that the HERs on different metal com- 
plex catalysts share the same mechanism in alkaline media. For all the catalysts, there should be active sites for water dissociation and other vacant positions for the adsorption of $\mathrm{H}$ ( $\left.\mathrm{H}_{\text {ads }}\right)$ in an appropriate force. If the binding force of $\mathrm{H}_{\text {ad }}$ is low, the first step of the Volmer reaction will become the rate-determining step. Meanwhile, the Heyrovsky reaction or the Tafel reaction is the important reaction process in HER catalysis. A small Tafel slope implies a fast reaction, which has a positive effect on the overpotential. 1D NW catalysts have the following structural advantages: (1) Large active surface/interface area and high density of active sites for different functions; (2) Small charge transfer resistance and fast electrode kinetics; and (3) Facilitating the diffusion of gas bubbles to prevent the catalyst from being destroyed.
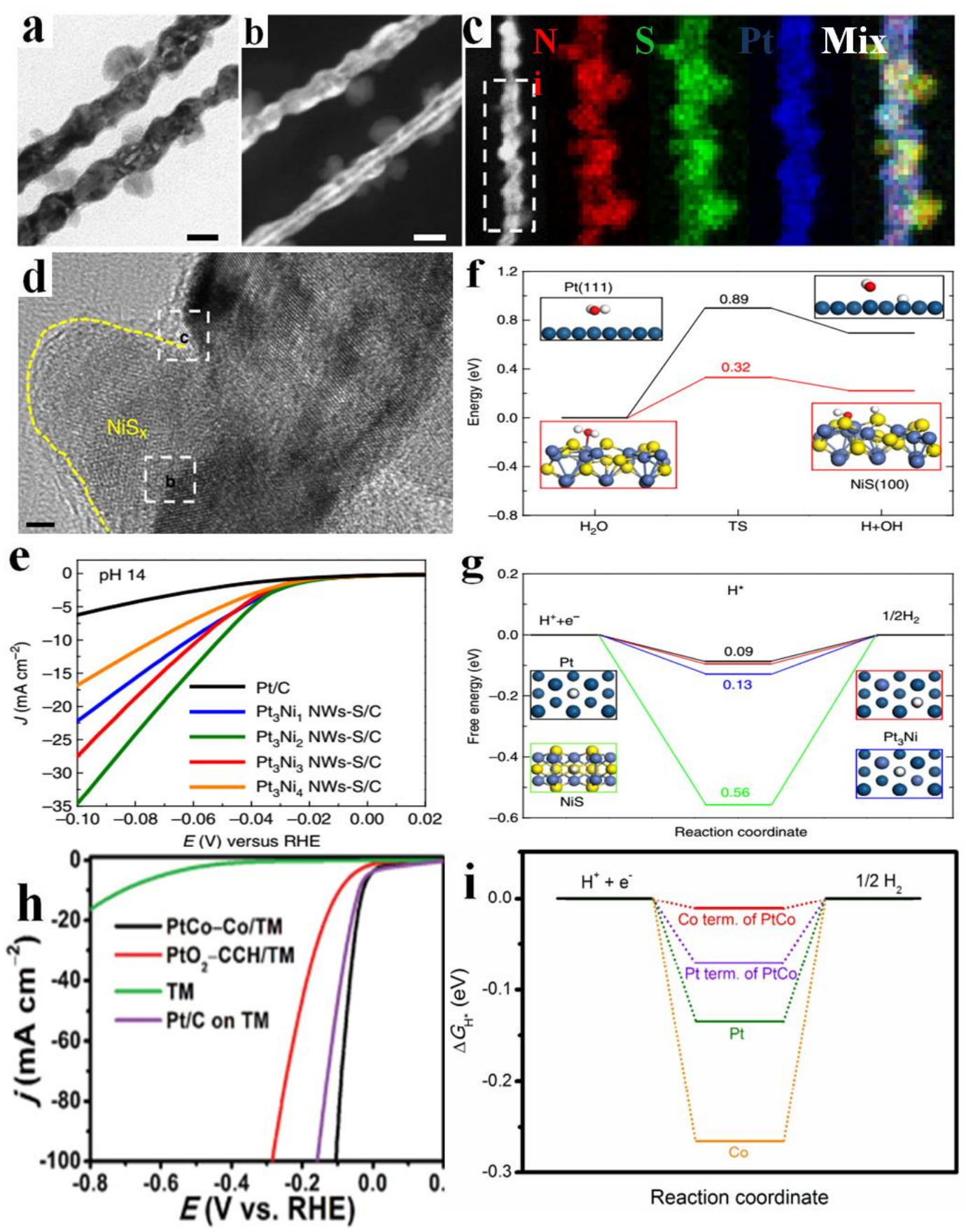

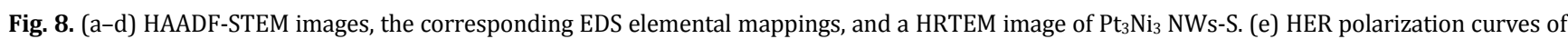
different Pt-Ni NWs-S/C and Pt/C at pH 14 and room temperature. (f, g) DFT simulations of the HER. (f) Reaction energy diagram of the dissociation of water. The initial state $\left(\mathrm{H}_{2} \mathrm{O}\right)$, transition state (TS), and final state $(\mathrm{H}+\mathrm{OH})$ are indicated in the diagram, along with the corresponding energy barriers on the two surfaces. (g) Free energy barriers for the HER. The red, white, yellow, dark blue, and light blue spheres represent $\mathrm{O}, \mathrm{H}, \mathrm{S}, \mathrm{Pt}$, and $\mathrm{Ni}$ atoms, respectively. Reproduced from Ref. [101] with permission from Nature. (h) LSV curves of the HER on different samples. (i) Free energy barriers for the HER on Pt [111], Co [111], and PtCo [100] surfaces with two inequivalent adsorption sites. Reproduced from Ref. [102] with the permission of the Royal Society of Chemistry. 

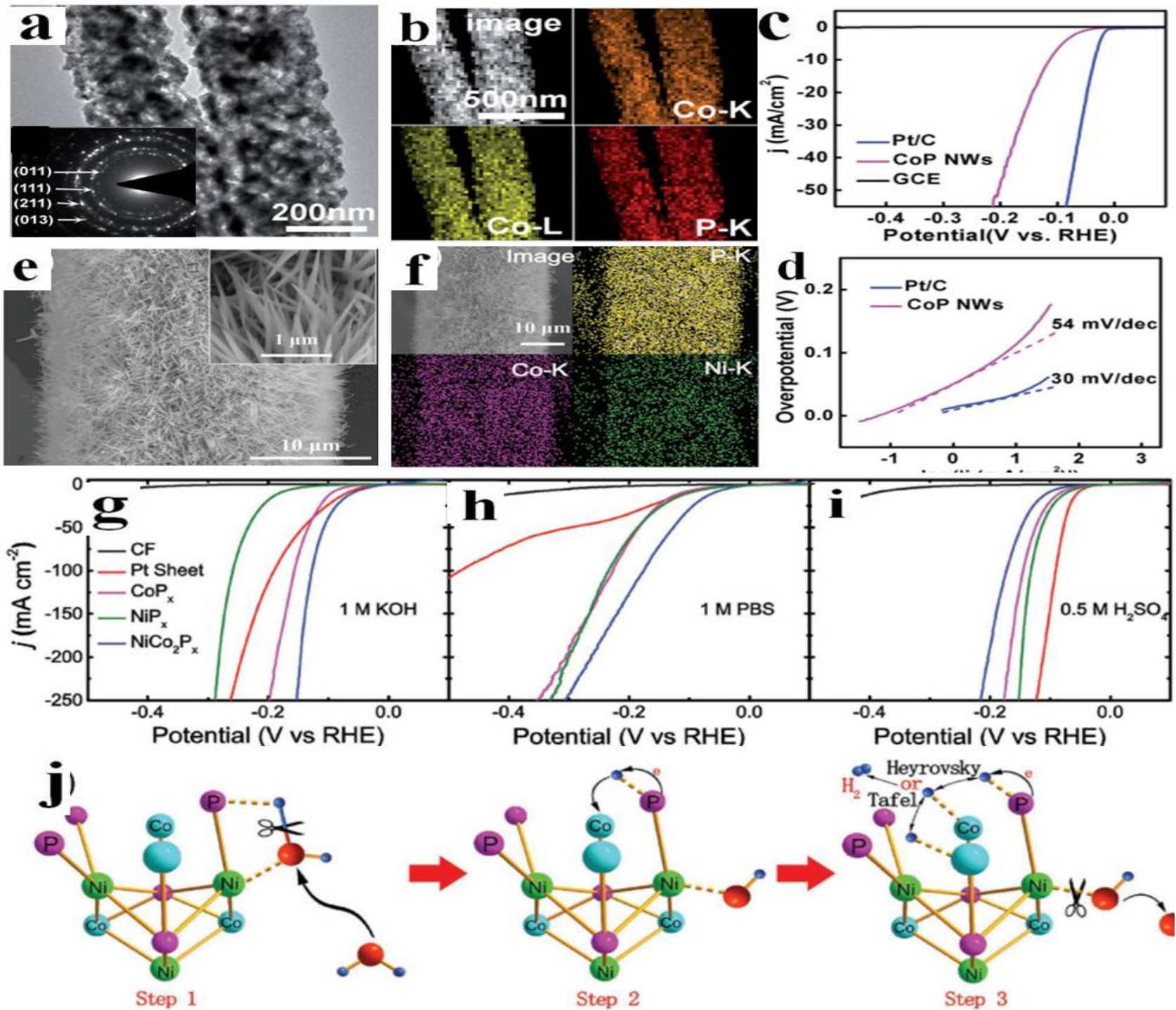

Fig. 9. (a) TEM image of CoP NWs. The inset shows a SAED pattern obtained from a single CoP NW. (b) STEM image and the corresponding EDS elemental mappings of the Co and P in the CoP NWs. (c, d) Polarization curves and Tafel plots of the HER occurring on CoP NWs and Pt/C. Reproduced from Ref. [102] with the permission of the Royal Society of Chemistry. (g-i) LSV curves of the HER obtained in three media. (j) Illustration of the water dissociation process in alkaline solutions. Reproduced from Ref. [107] with permission from Wiley-VCH.

\subsection{D nanostructured catalysts for the OER}

The electrochemical OER is another half-reaction of the WS process. The product $\mathrm{O}_{2}$ molecule is useful for the chemical industry $[114,115]$. Up to now, Ru and Ir oxides are deemed as the high-performance OER electrocatalysts. On the other hand, Pt oxides exhibit very sluggish kinetics for the OER, which is even inferior to those of most transition-metal oxides. Transition-metal oxides are a class of low-cost high-efficiency catalysts that are promising alternative candidates for WS. It has been well accepted that the OER is multistep and includes the following reactions: (1) Formation of ${ }^{*} \mathrm{OH}$ from the $\mathrm{H}_{2} \mathrm{O} / \mathrm{OH}^{-}$ adsorbed on the active sites; (2) Decomposition of * $\mathrm{OH}$ to ${ }^{*} \mathrm{O}$; (3) Transformation of ${ }^{*} \mathrm{O}$ into the ${ }^{*} \mathrm{OOH}$ intermediate; and (4) Generation of $\mathrm{O}_{2}$ molecules from ${ }^{*} \mathrm{OOH}$. The OER processes in acid and alkali media are described as follows [8,116,117].
In acidic solutions

$$
\begin{aligned}
& \text { Overall reaction: } 2 \mathrm{H}_{2} \mathrm{O} \rightarrow \mathrm{O}_{2}+4 \mathrm{H}^{+}+4 \mathrm{e}^{-} \\
& \mathrm{H}_{2} \mathrm{O}+{ }^{*} \rightarrow \mathrm{H}^{+}+\mathrm{e}^{-}+{ }^{*} \mathrm{OH} \\
& \\
& * \mathrm{OH} \rightarrow \mathrm{H}^{+}+\mathrm{e}^{-}+{ }^{*} \mathrm{O} \\
& \quad{ }^{*} \mathrm{O}+\mathrm{H}_{2} \mathrm{O} \rightarrow \mathrm{H}^{+}+\mathrm{e}^{-}+\mathrm{OOH}^{*} \\
& \quad{ }^{*} \mathrm{OOH} \rightarrow \mathrm{H}^{+}+\mathrm{e}^{-}+\mathrm{O}_{2}+*
\end{aligned}
$$

In alkaline solutions

$$
\begin{aligned}
& \text { Overall reaction: } 4 \mathrm{OH}^{-} \rightarrow \mathrm{O}_{2}+2 \mathrm{H}_{2} \mathrm{O}+4 \mathrm{e}^{-} \\
& \quad *+\mathrm{OH}^{-} \rightarrow{ }^{*} \mathrm{OH}+\mathrm{e}^{-} \\
& \quad * \mathrm{OH}+\mathrm{OH}^{-} \rightarrow \mathrm{H}_{2} \mathrm{O}+{ }^{*} \mathrm{O}+\mathrm{e}^{-} \\
& \quad * \mathrm{O}+\mathrm{OH}^{-} \rightarrow{ }^{*} \mathrm{OOH}+\mathrm{e}^{-} \\
& \quad{ }^{*} \mathrm{OOH}+\mathrm{OH}^{-} \rightarrow{ }^{*}+\mathrm{O}_{2}+\mathrm{e}^{-}
\end{aligned}
$$

Here, * represents the active site, whereas $\mathrm{OH}^{*}, \mathrm{O}^{*}$, and $\mathrm{OOH}^{*}$ refer to the adsorbed intermediate species.

It is obvious that $\mathrm{O}_{2}$ gas is formed via multistep reactions and that a high overpotential is needed for the four-electron transfer process. Developing nanostructured catalysts with 
Table 3

Comparison of the HER performances of various one-dimensional nanostructured materials.

\begin{tabular}{|c|c|c|c|c|c|}
\hline Catalyst & $\begin{array}{c}\text { Over } \\
\text { potential } \\
\eta_{10}(\mathrm{mV})\end{array}$ & $\begin{array}{c}\text { Tafel } \\
\text { slope } \\
(\mathrm{mV} / \mathrm{dec})\end{array}$ & Electrolyte & $\begin{array}{l}\text { Stability } \\
\text { test } \\
\text { (h) }\end{array}$ & Ref. \\
\hline PtNi NWs & 40 & - & $1 \mathrm{M} \mathrm{KOH}$ & 3 & [100] \\
\hline PtCo-Co/TiM & 28 & 35 & $1 \mathrm{M} \mathrm{KOH}$ & 50 & [103] \\
\hline $\begin{array}{l}\mathrm{Pd} / \mathrm{Cu}-\mathrm{Pt} \text { na- } \\
\text { norings }\end{array}$ & 22.8 & 25 & $0.5 \mathrm{M} \mathrm{H}_{2} \mathrm{SO}_{4}$ & 15 & [104] \\
\hline $\mathrm{Pt}_{3} \mathrm{Ni}_{2} \mathrm{NWs}-\mathrm{S} / \mathrm{C}$ & $70\left(\eta_{19}\right)$ & - & $1 \mathrm{M} \mathrm{KOH}$ & 5 & [101] \\
\hline Ir WNWs & $\begin{array}{l}15.4 \\
11.3\end{array}$ & $\begin{array}{l}30.1 \\
29.8\end{array}$ & $\begin{array}{l}0.5 \mathrm{M} \mathrm{HClO}_{4} \\
0.1 \mathrm{M} \mathrm{HClO}_{4}\end{array}$ & 6.9 & [105] \\
\hline CoP NWs & 110 & 54 & $0.5 \mathrm{M} \mathrm{H}_{2} \mathrm{SO}_{4}$ & 48 & [102] \\
\hline $\mathrm{MoP} / \mathrm{CNT}$ & $\begin{array}{c}83 \\
102 \\
86\end{array}$ & $\begin{array}{c}60 \\
115 \\
73\end{array}$ & $\begin{array}{c}0.5 \mathrm{M} \mathrm{H}_{2} \mathrm{SO}_{4} \\
1 \mathrm{M} \mathrm{PBS} \\
1 \mathrm{M} \mathrm{KOH}\end{array}$ & 40 & [93] \\
\hline $\begin{array}{l}\mathrm{Ni} / \mathrm{NiO} / \mathrm{CoSe}_{2} \\
\mathrm{NBs}\end{array}$ & $30\left(\eta_{0}\right)$ & 39 & $0.5 \mathrm{M} \mathrm{H}_{2} \mathrm{SO}_{4}$ & - & [94] \\
\hline FeCoNi-HNTAs & 58 & 37.5 & $1 \mathrm{M} \mathrm{KOH}$ & 80 & [96] \\
\hline CoP NWs/CC & 67 & 51 & $0.5 \mathrm{M} \mathrm{H}_{2} \mathrm{SO}_{4}$ & 22.2 & [106] \\
\hline $\mathrm{NiCo}_{2} \mathrm{P}_{\mathrm{x}} \mathrm{NWs}$ & $\begin{array}{l}104 \\
63 \\
58\end{array}$ & $\begin{array}{l}59.6 \\
63.3 \\
34.3\end{array}$ & $\begin{array}{c}0.5 \mathrm{M} \mathrm{H}_{2} \mathrm{SO}_{4} \\
1 \mathrm{M} \mathrm{PBS} \\
1 \mathrm{M} \mathrm{KOH}\end{array}$ & 30 & [107] \\
\hline NiSe NWs/NF & 96 & 120 & $1 \mathrm{M} \mathrm{KOH}$ & 12 & [108] \\
\hline$\beta-\mathrm{Mo}_{2} \mathrm{C}$ NTs & $\begin{array}{l}172 \\
112\end{array}$ & $\begin{array}{l}62 \\
55\end{array}$ & $\begin{array}{c}0.1 \mathrm{M} \mathrm{KOH} \\
0.5 \mathrm{M} \mathrm{H}_{2} \mathrm{SO}_{4}\end{array}$ & 8 & [109] \\
\hline Fe-CoP NAs/Ti & 78 & 75 & $1 \mathrm{M} \mathrm{KOH}$ & 20 & [110] \\
\hline
\end{tabular}

abundant electrochemically active sites is an effective strategy to improve the electrocatalytic activity and reduce the overpotential for the OER. In particular, 1D nanocatalysts with fast charge transfer and large surface areas demonstrate great potential in OER electrocatalysis.

\subsubsection{D noble-metal-based nanostructures for the OER}

Currently, noble metals, including Ir, Ru, Pt and their compounds, exhibit outstanding catalytic activities for the OER in both aqueous acidic and alkaline media [118]. The first investigation on the electrode kinetics of the OER on Pt, Rh, and Ir can be dated back to 1966 . The study showed that the activities of the metal catalysts for the OER in acidic solutions follow the order of $\mathrm{Ru}>\mathrm{Ir}>\mathrm{Pd}>\mathrm{Rh}>\mathrm{Pt}$ and that Pt was not an effective catalyst for the OER $[119,120]$. It was found that during the OER process, it is easy to convert a single precious metal into a metal oxide film at high anodic potentials. Among the metal oxides, Ru/Ir-based oxides are the most efficient OER electrocatalysts (Fig. 10(a)). According to theoretical studies on the binding energies of the reaction intermediates, $\mathrm{IrO}_{2}$ is a highly active metal oxide catalyst in an acidic medium, but is not a desired OER catalyst from the perspective of stability. Recently, Zhang and coworkers [121] synthesized PtIr alloy nanocatalysts with tunable shapes that showed excellent catalytic activities for the OER. The activity tests indicated that the amount of the $\mathrm{Ir} / \mathrm{IrO}{ }_{x}$ species on the surface is positively correlated with the catalytic ability for water dissociation; in contrast, the amount of surface Pt atoms showed a negative correlation with the activity. After the alloying of Pt with Ir, partial charge transfer from Ir to Pt occurs that produces a surface alloying effect, which can weaken the water adsorption and dissociation processes and thus alter the rate-determining step of the reaction. Several studies have indicated that the actual catalytic properties of electrocatalysts are largely dependent on the surface properties, such as crystal facets, ECSA, roughness factors, and the local electronic structures [105,119,122,123].

\subsubsection{D non-noble-metal-based nanostructures for the OER}

The exorbitant price and the relative scarcity of the noble-metal-based catalysts mentioned above severely restrict their universal practical application. Recently, non-precious metal-based nanostructures have become the focus point, as they are promising alternatives for the expensive precious metals [131-133]. Owing to their interesting electronic properties, high elemental abundances, high conductivities, and high corrosion resistances, $\mathrm{Ni}$ - and Co-based metal catalysts, such as alloys, oxides (hydroxides), and phosphates, exhibit highly efficient catalytic performances for the OER [125,134-137]. For example, $\mathrm{Co}_{3} \mathrm{O}_{4}$ NWs were reported to exhibit ideal OER performance with high activity and corrosion resistance. Wu and coworkers [126] prepared Ni-doped $\mathrm{Co}_{3} \mathrm{O}_{4} \mathrm{NW}$ catalysts for the OER. The authors found that after the incorporation of $\mathrm{Ni}$ into $\mathrm{Co}_{3} \mathrm{O}_{4}$, the surface of the NWs became rough, thereby exposing more active sites. Compared with the $\mathrm{Co}_{3} \mathrm{O}_{4} \mathrm{NWs}, \mathrm{Ni}_{x} \mathrm{Co}_{3-\mathrm{x}} \mathrm{O}_{4}$ NWs exhibited enhanced OER electrocatalytic properties. The synergistic effect between two different heteroatoms can improve the surface adsorption performance of NWs, which is beneficial for the electrocatalytic properties. Subsequently, Zhang and coworkers synthesized $\mathrm{NiCoO}_{2} \mathrm{NWs}$ on a carbon fiber paper [124]. The $\mathrm{NiCoO}_{2} \mathrm{NWs}$ with $\mathrm{NaCl}$-type structure are highly efficient catalysts for the OER in $0.1 \mathrm{M} \mathrm{KOH} \mathrm{(Fig.}$ $10(\mathrm{~b}))$, displaying only a small overpotential $\left(\eta_{10}=0.303 \mathrm{~V}\right)$. Such a structure showed a tendency to transform in situ into an hydroxide/oxyhydroxide species, which present active sites for the OER [138]. This process occurs at around $1.35 \mathrm{~V}$ as follows:

$$
\begin{gathered}
\mathrm{NiCoO}_{2}+2 \mathrm{OH}^{-} \rightarrow \mathrm{NiOOH}+\mathrm{CoOOH}+2 \mathrm{e}^{-} \\
\mathrm{CoOOH}+\mathrm{OH}^{-} \rightarrow \mathrm{CoO}_{2}+\mathrm{H}_{2} \mathrm{O}+\mathrm{e}^{-} \\
\mathrm{Ni}^{2+} \rightarrow \mathrm{Ni}^{3+}+\mathrm{e}^{-}
\end{gathered}
$$

Furthermore, the carbon fiber paper substrate helps to improve the stability and conductivity of materials. The $\mathrm{NiCoO}_{2}$ NWs can undergo $12 \mathrm{~h}$ of continuous operation without exhibiting an obvious drop in the current density. Meanwhile, Fe doping is also a feasible strategy to further promote the catalytic activities of Ni-based catalysts for the OER [127]. Zhang et al. [128] designed and synthesized a unique mesoporous $\mathrm{NiFeO}$ NW network structure. One structure of $\mathrm{Ni}_{2} \mathrm{Fe}_{1} \mathrm{O}$ showed a relatively low overpotential $\left(\eta_{10}=244 \mathrm{mV}\right)$ and excellent long-term stability ( $60 \mathrm{~h}$, with negligible degradation) for the OER in $1 \mathrm{M} \mathrm{KOH}$. In particular, the $\mathrm{Ni}_{x} \mathrm{Fe}_{y} \mathrm{O}$ NWs with various Ni: Fe ratios exhibited different performances: $\mathrm{Ni}_{2} \mathrm{Fe}_{1} \mathrm{O}\left(\eta_{10}=\right.$ $244 \mathrm{mV})>\mathrm{Ni}_{1.5} \mathrm{Fe}_{1.5} \mathrm{O}\left(\eta_{10}=290 \mathrm{mV}\right)>\mathrm{Ni}_{1} \mathrm{Fe}_{2} \mathrm{O}\left(\eta_{10}=316 \mathrm{mV}\right)$ $>\operatorname{IrO}_{2}\left(\eta_{10}=339 \mathrm{mV}\right)$. The results suggest that a high $\mathrm{Ni}$ content can increase the electron transport capability and facilitate the OER process to a great extent. Besides, the obtained results are in good agreement with the previously reported results of maximum OER activity for Fe-doped $\mathrm{NiOOH}$ when the concen- 

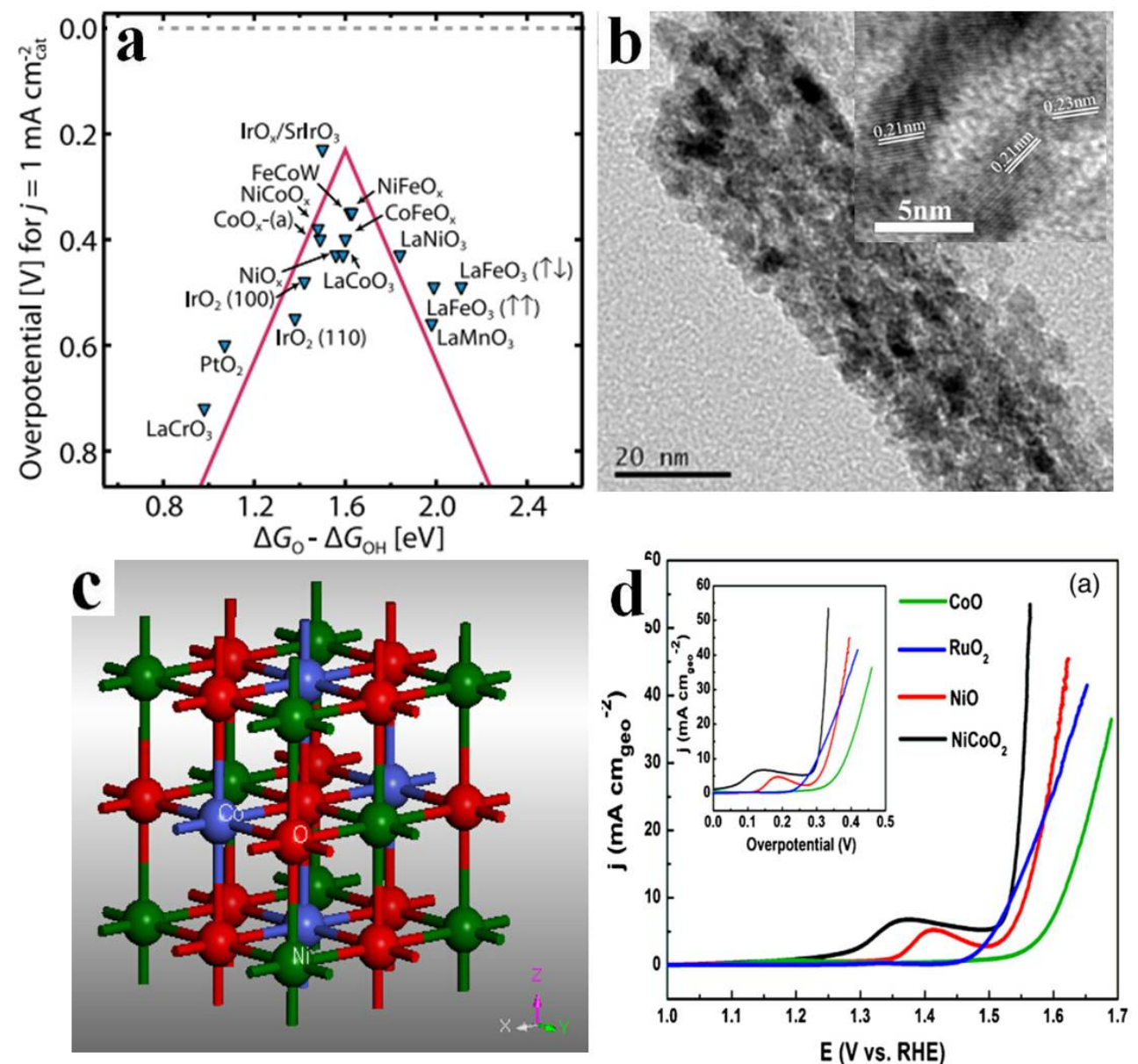

Fig. 10. (a) OER volcano plot for different metal oxides. Reproduced from Ref. [1] with permission from Science. (b) TEM image of a NiCoO $\mathrm{NW}^{\mathrm{NW}}$ (c) Crystal structure of the $\mathrm{NiCoO}_{2}$ unit cell with the NaCl-type structure. (d) Polarization curves for the OER on modified carbon fiber paper electrodes that comprised $\mathrm{NiO}, \mathrm{CoO}, \mathrm{NiCoO}_{2}$, and $\mathrm{RuO}_{2}$. The inset of figure (d) shows the corresponding plots of the current density vs. the overpotential. Reproduced from Ref. [124] with permission from Elsevier.

tration of Fe is as high as 35\% [139]. In another study, Zhang et

Table 4

Comparison of the OER performances of various one-dimensional nanostructured materials.

\begin{tabular}{|c|c|c|c|c|c|}
\hline Catalyst & $\begin{array}{c}\text { Over } \\
\text { potential } \\
\eta_{10}(\mathrm{~V})\end{array}$ & $\begin{array}{c}\text { Tafel } \\
\text { slope } \\
\text { (mV/dec) }\end{array}$ & Electrolyte & $\begin{array}{l}\text { Stability } \\
\text { test } \\
\text { (h) }\end{array}$ & Ref. \\
\hline Ir WNWs & 270 & 43.6 & $0.5 \mathrm{M} \mathrm{HClO}_{4}$ & 6.9 & {$[105]$} \\
\hline Pt-Ir NWs & $\begin{array}{c}\text { MA } 17.6 \\
\text { A/g }\left(\eta_{25}\right)\end{array}$ & 79 & $0.5 \mathrm{M} \mathrm{H}_{2} \mathrm{SO}_{4}$ & - & [121] \\
\hline FeCoNi-HNTAs & 184 & 49.9 & $1 \mathrm{M} \mathrm{KOH}$ & 100 & [96] \\
\hline NiSe NWs /NF & $270\left(\eta_{20}\right)$ & 64 & $1 \mathrm{M} \mathrm{KOH}$ & 12 & [108] \\
\hline Fe-CoP NAs/Ti & 230 & 93 & $1 \mathrm{M} \mathrm{KOH}$ & 20 & [110] \\
\hline $\mathrm{FeOOH} / \mathrm{Co} / \mathrm{FeOOH}$ & 250 & 32 & $1 \mathrm{M} \mathrm{NaOH}$ & 50 & [117] \\
\hline $\mathrm{NiCoO}_{2} \mathrm{NWs}$ & 303 & 57 & $1 \mathrm{M} \mathrm{KOH}$ & 12 & [124] \\
\hline NiSe NWs /CFs & $318\left(\eta_{50}\right)$ & 46 & $1 \mathrm{M} \mathrm{KOH}$ & 120 & [125] \\
\hline $\mathrm{Ni}_{x} \mathrm{Co}_{3-x} \mathrm{O}_{4} \mathrm{NWS}$ & - & 60 & $1 \mathrm{M} \mathrm{NaOH}$ & - & [126] \\
\hline $\mathrm{Co}_{3} \mathrm{FeN}_{x} \mathrm{NWS}$ & $222\left(\eta_{20}\right)$ & 46 & $1 \mathrm{M} \mathrm{KOH}$ & 8.3 & [127] \\
\hline NiFeO NWs & 224 & 39 & $1 \mathrm{M} \mathrm{KOH}$ & 60 & [128] \\
\hline $\mathrm{Ni}_{2} \mathrm{Fe}_{1}-\mathrm{Mo} \mathrm{NWs}$ & 231 & 39 & $1 \mathrm{M} \mathrm{KOH}$ & 15 & [129] \\
\hline $\mathrm{Co}_{4} \mathrm{~N}$ porous $\mathrm{NWs}$ & 257 & 44 & $1 \mathrm{M} \mathrm{KOH}$ & 12 & [130] \\
\hline
\end{tabular}

al. [129] synthesized an advanced porous Mo-doped NiFeO NW catalyst. Compared with the $\mathrm{Ni}_{x} \mathrm{Fe}_{y} \mathrm{O}$ NWs, the Mo-doped $\mathrm{NiFeO}$ NWs exhibited enhanced OER activity, with a small overpotential $\left(\eta_{10}=231 \mathrm{mV}\right)$ in $1 \mathrm{M} \mathrm{KOH}$. For the Mo-doped NiFeO NWs, the outstanding catalytic properties observed can be attributed to a well-designed heteroatom-doped porous NW network, an enlarged active surface area, the synergistic effect between Mo and $\mathrm{NiFe}$, and the enhanced electrical conductivity. Overall, the following factors may have an influence on the OER performances of the catalysts: (1) composition; (2) crystal structure or shape; (3) electrical conductivity; and (4) hierarchical porous structure and the surface chemical states of the metals.

\section{Summary and outlook}

Energy electrocatalysis has been recognized as a hot research field in recent years owing to its importance in fundamental technological applications. In the past few decades, numerous research efforts have been devoted to searching for novel cost-efficient electrocatalysts for DFMCs and WS. Herein, we have reviewed the recent developments in 1D nanomaterials and their applications for the ORR, MOR, HER, and OER. We 
have also briefly discussed the reaction mechanisms. Based on previous studies, we note that there are still some promising catalysts, but a few challenging tasks must be accomplished. First, it is of crucial importance to understand the real active sites of various catalysts, especially 1D nanostructures, for the different reactions. To this end, both experimental and computational studies should be carried out simultaneously so that high-performance catalysts can be designed and prepared purposefully. Secondly, morphology and composition are two crucial factors that determine the catalytic activity, stability, and durability of materials. The 1D nanostructure has showed excellent catalytic stability, with negligible aggregation, during the electrochemical reactions. How to further improve the catalytic performances of the 1D nanostructures by controlling the composition and surface facets is still a challenge. Thirdly, the electrocatalysts should have large surface areas to speed up the proton and electron transfers and the desorption of the intermediates and gas products from the surface of the catalysts and to release more active sites for further electrochemical reactions. Therefore, much effort is needed in the synthesis of ultrathin but stable 1D nanomaterials.

It is promising that the electrocatalytic properties of $1 \mathrm{D}$ nanostructures, including selectivity, activity, and durability, can be effectively enhanced through continuous optimization on the basis of multiscale principles. This review summarizes the application of 1D nanostructures in energy electrocatalysis, which is also useful for understanding the other electrocatalytic processes, such as the $\mathrm{CO}_{2}$ reduction reaction, nitrogen reduction reaction, and chlorine production. In summary, developing novel electrocatalysts with optimal compositions and surface structures to solve the drawbacks of the present catalysts will always be desired, but there is still a long way to go in this regard.

\section{References}

[1] Z. W. Seh, J. Kibsgaard, C. F. Dickens, I. Chorkendorff, J. K. Norskov, T. F. Jaramillo, Science, 2017, 355, eaad4998.

[2] C. Steinlechner, H. Junge, Angew. Chem. Int. Ed., 2018, 57, 44- 45.

[3] M. K. Debe, Nature, 2012, 486, 43-51.

[4] M. Zhou, Y. Xu, Y. Lei, Nano Today, 2018, 20, 33-57.

[5] P. Yang, J. M. Tarascon, Nat. Mater., 2012, 11, 560-563.

[6] F. Lin, K. Wang, Y. Tang, J. Lai, M. Luo, M. Huang, S. Guo, Chem. Commun., 2017, 54, 1315-1318.

[7] Y. Zheng, Y. Jiao, M. Jaroniec, Y. Jin, S. Z. Qiao, Small, 2012, 8, 3550-3566.

[8] Y. Jiao, Y. Zheng, M. Jaroniec, S. Z. Qiao, Chem. Soc. Rev., 2015, 44, 2060-2086.

[9] L. Gong, Z. Yang, K. Li, W. Xing, C. Liu, J. Ge, J. Energy Chem., 2018,

\section{Graphical Abstract}

Chin. J. Catal., 2019, 40: 4-22 doi: 10.1016/S1872-2067(18)63177-8

Recent advances in one-dimensional nanostructures for energy electrocatalysis

Ping Li, Wei Chen *

Changchun Institution of Applied Chemistry, Chinese Academic of Sciences;

University of Science and Technology of China

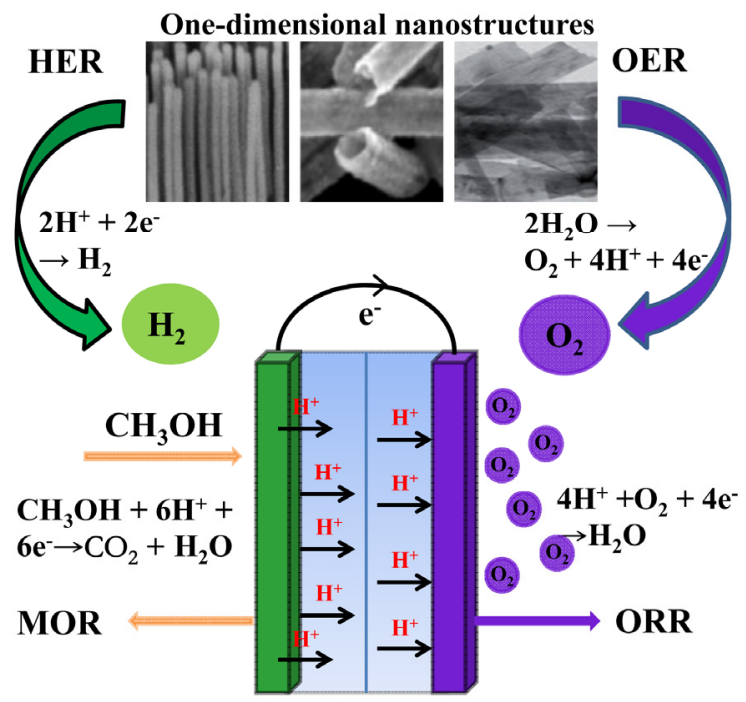

This overview summarizes the recent advances in one-dimensional metal nanostructures for energy electrocatalysis, including the main reactions in direct methanol fuel cells and water splitting. 
27, 1618-1628.

[10] C. H. Choi, M. Kim, H. C. Kwon, S. J. Cho, S. Yun, H. T. Kim, K. J. Mayrhofer, H. Kim, M. Choi, Nat. Commun., 2016, 7, 10922.

[11] J. Liu, M. Jiao, L. Lu, H. M. Barkholtz, Y. Li, Y. Wang, L. Jiang, Z. Wu, D. J. Liu, L. Zhuang, C. Ma, J. Zeng, B. Zhang, D. Su, P. Song, W. Xing, W. Xu, Y. Wang, Z. Jiang, G. Sun, Nat. Commun., 2017, 8, 15938.

[12] P. Song, M. Luo, X. Liu, W. Xing, W. Xu, Z. Jiang, L. Gu, Adv. Funct. Mater., 2017, 27, 1700802.

[13] Y. Peng, B. Lu, S. Chen, Adv. Mater., 2018, e1801995.

[14] L. Zhang, L. Han, H. Liu, X. Liu, J. Luo, Angew. Chem. Int. Ed., 2017, 56, 13694-13698.

[15] S. Yang, J. Kim, Y. J. Tak, A. Soon, H. Lee, Angew. Chem. Int. Ed., 2016, 55, 2058-2062.

[16] B. Wurster, D. Grumelli, D. Hotger, R. Gutzler, K. Kern, J. Am. Chem. Soc., 2016, 138, 3623-3626.

[17] M. Jahan, Z. Liu, K. P. Loh, Adv. Funct. Mater., 2013, 23, 5363-5372.

[18] Y. Yu, F. Cui, J. Sun, P. Yang, Nano Lett., 2016, 16, 3078-3084.

[19] B. Y. Xia, H. B. Wu, Y. Yan, X. W. Lou, X. Wang, J. Am. Chem. Soc., 2013, 135, 9480-9485.

[20] Y. Xia, P. Yang, Y. Sun, Y. Wu, B. Mayers, B. Gates, Y. Yin, F. Kim, H. Yan, Adv. Mater., 2003, 15, 353-389.

[21] L. Mai, J. Sheng, L. Xu, S. Tan, J. Meng, Acc. Chem. Res., 2018, 51, 950-959.

[22] Y. Xiong, Y. Yang, F. J. DiSalvo, H. D. Abruna, J. Am. Chem. Soc., 2018, 140, 7248-7255.

[23] S. Guo, S. Zhang, S. Sun, Angew. Chem. Int. Ed., 2013, 52, 8526-8544.

[24] S. Siahrostami, A. Verdaguer-Casadevall, M. Karamad, D. Deiana, P. Malacrida, B. Wickman, M. Escudero-Escribano, E. A. Paoli, R. Frydendal, T. W. Hansen, I. Chorkendorff, I. E. L. Stephens, J. Rossmeisl, Nat. Mater., 2013, 12, 1137-1143.

[25] C. Du, X. Gao, W. Chen, Chin. J. Catal., 2016, 37, 1049-1061.

[26] F. Calle-Vallejo, J. Tymoczko, V. Colic, Q. H. Vu, M. D. Pohl, K. Morgenstern, D. Loffreda, P. Sautet, W. Schuhmann, A. S. Bandarenka, Science, 2015, 350, 185-189.

[27] J. K. Nørskov, J. Rossmeisl, A. Logadottir, L. Lindqvist, J. R. Kitchin, T. Bligaard, H. Jonsson, J. Phys. Chem. B, 2004, 108, 17886-17892.

[28] Y. Peng, B. Lu, N. Wang, L. Li, S. Chen, Phys. Chem. Chem. Phys., 2017, 19, 9336-9348.

[29] Z. L. Zhao, Q. Wang, L. Y. Zhang, H. M. An, Z. Li, C. M. Li, Electrochim. Acta, 2018, 263, 209-216.

[30] L. Bu, J. Ding, S. Guo, X. Zhang, D. Su, X. Zhu, J. Yao, J. Guo, G. Lu, X. Huang, Adv. Mater., 2015, 27, 7204-7212.

[31] R. Lin, X. Cai, H. Zeng, Z. Yu, Adv. Mater., 2018, 30, e1705332.

[32] K. Jiang, D. Zhao, S. Guo, X. Zhang, X. Zhu, J. Guo, G. Lu, X. Huang, Sci. $A d v ., 2017,3$, e1601705.

[33] K. Jiang, Q. Shao, D. Zhao, L. Bu, J. Guo, X. Huang, Adv. Funct. Mater., 2017, 27, 1700830 .

[34] Y. Ma, W. Gao, H. Shan, W. Chen, W. Shang, P. Tao, C. Song, C. Addiego, T. Deng, X. Pan, J. Wu, Adv. Mater., 2017, 29, 1703460.

[35] L. Tao, D. Yu, J. Zhou, X. Lu, Y. Yang, F. Gao, Small, 2018, 14, 1704503-1170459.

[36] J. Zhang, K. Sasaki, E. Sutter, R. R. Adzic, Science, 2007, 135, 220-222.

[37] T. Kwon, M. Jun, H. Y. Kim, A. Oh, J. Park, H. Baik, S. H. Joo, K. Lee, Adv. Funct. Mater., 2018, 28, 1706440.

[38] L. Wang, W. Gao, Z. Liu, Z. Zeng, Y. Liu, M. Giroux, M. Chi, G. Wang, J. Greeley, X. Pan, C. Wang, ACS Catal., 2017, 8, 35-42.

[39] H. Huang, K. Li, Z. Chen, L. Luo, Y. Gu, D. Zhang, C. Ma, R. Si, J. Yang, Z. Peng, J. Zeng, J. Am. Chem. Soc., 2017, 139, 8152-8159.

[40] M. A. Hoque, F. M. Hassan, D. Higgins, J. Y. Choi, M. Pritzker, S. Knights, S. Ye, Z. Chen, Adv. Mater., 2015, 27, 1229-1234.
[41] L. Bu, S. Guo, X. Zhang, X. Shen, D. Su, G. Lu, X. Zhu, J. Yao, J. Guo, X. Huang, Nat. Commun., 2016, 7, 11850.

[42] C. Koenigsmann, E. Sutter, R. R. Adzic, S. S. Wong, J. Phys. Chem. C, 2012, 116, 15297-15306.

[43] C. Koenigsmann, E. Sutter, T. A. Chiesa, R. R. Adzic, S. S. Wong, Nano Lett., 2012, 12, 2013-2020.

[44] T. Zhou, R. Ma, Y. Zhou, R. Xing, Q. Liu, Y. Zhu, J. Wang, Microporous Mesoporous Mater., 2018, 261, 88-97.

[45] Y. Ye, H. Li, F. Cai, C. Yan, R. Si, S. Miao, Y. Li, G. Wang, X. Bao, ACS Catal., 2017, 7, 7638-7646.

[46] J. C. Li, P. X. Hou, C. Liu, Small, 2017, 13, 1702002.

[47] X. Huang, N. Zheng, J. Am. Chem. Soc., 2009, 131, 4602-4603.

[48] N. Lu, W. Chen, G. Fang, B. Chen, K. Yang, Y. Yang, Z. Wang, S. Huang, Y. Li, Chem. Mater., 2014, 26, 2453-2459.

[49] X. Ma, Y. Guo, J. Jin, B. Zhao, W. Song, RSC Adv., 2017, 7, 41962-41969.

[50] S. J. Kim, S. C. Lee, C. Lee, M. H. Kim, Y. Lee, Nano Energy, 2018, 48, 134-143.

[51] A. Holewinski, J. C. Idrobo, S. Linic, Nat. Chem. 2014, 6, 828-834.

[52] L. Yang, J. Yu, Z. Wei, G. Li, L. Cao, W. Zhou, S. Chen, Nano Energy, 2017, 41, 772-779.

[53] S. K. Bikkarolla, F. Yu, W. Zhou, P. Joseph, P. Cumpson, P. Papakonstantinou, J. Mater. Chem. A, 2014, 2, 14493-14501.

[54] L. Zeng, T. S. Zhao, L. An, J. Mater. Chem. A, 2015, 3, 1410-1416.

[55] Y. Wang, X. Lu, Y. Liu, Y. Deng, Electrochem. Commun., 2013, 31, 108-111.

[56] A. Yu, C. Lee, N. S. Lee, M. H. Kim, Y. Lee, ACS Appl. Mater. Interfaces, 2016, 8, 32833-32841.

[57] H. Huang, A. Ruditskiy, S. I. Choi, L. Zhang, J. Liu, Z. Ye, Y. Xia, ACS Appl. Mater. Interfaces, 2017, 9, 31203-31212.

[58] C. Koenigsmann, S. S. Wong, Energy Environ. Sci., 2011, 4, 1161-1176.

[59] L. Lin, Q. Zhu, A. Xu, Prog. Chem., 2015, 27, 1147-1157.

[60] R. N. Singh, R. Awasthi, C. S. Sharma, Int. J. Electrochem. Sci., 2014, 9, 5607-5639.

[61] E. A. Batista, G. R. P. Malpass, A. J. Motheo, T. Iwasita, J. Electroanal. Chem., 2004, 571, 273-282.

[62] E. A. Batista, H. Hoster, T. Iwasita, J. Electroanal. Chem., 2003, 554-555, 265-271.

[63] T. Yajima, H. Uchida, M. Watanabe, J. Phys. Chem. B, 2004, 108, 2654-2659.

[64] J. S. Spendelow, Q. Xu, J. D. Goodpaster, P. J. A. Kenis, A. Wieckowski, J. Electrochem. Soc., 2007, 154, F238.

[65] S. M. Alia, G. Zhang, D. Kisailus, D. Li, S. Gu, K. Jensen, Y. Yan, Adv. Funct. Mater, 2010, 20, 3742-3746.

[66] C. Koenigsmann, A. C. Santulli, K. Gong, M. B. Vukmirovic, W. P. Zhou, E. Sutter, S. S. Wong, R. R. Adzic, J. Am. Chem. Soc., 2011, 133, 9783-9795.

[67] S. Guo, S. Zhang, X. Sun, S. Sun, J. Am. Chem. Soc., 2011, 133, 15354-15357.

[68] J. Pei, J. Mao, X. Liang, Z. Zhuang, C. Chen, Q. Peng, D. Wang, Y. Li, ACS Sustain. Chem. Eng., 2017, 6, 77-81.

[69] A. Cuesta, M. Escudero, B. Lanova, H. Baltruschat, Langmuir, 2009, $25,6500-6507$.

[70] A. Garg, M. Milina, M. Ball, D. Zanchet, S. T. Hunt, J. A. Dumesic, Y. Roman-Leshkov, Angew. Chem. Int. Ed., 2017, 56, 8828-8833.

[71] S. S. Laletina, M. Mamatkulov, E. A. Shor, V. V. Kaichev, A. Genest, I. V. Yudanov, N. Rösch, J. Phys. Chem. C, 2017, 121, 17371-17377.

[72] Y. Lu, Y. Jiang, H. Wu, C. Wei, J. Phys. Chem. C, 2012, 117, 2926-2938.

[73] Z. Chen, Y. C. He, J. H. Chen, X. Z. Fu, R. Sun, Y. X. Chen, C. P. Wong, J. Phys. Chem. C, 2018, 122, 8976-8983. 
[74] J. X. Tang, Q. S. Chen, L. X. You, H. G. Liao, S. G. Sun, S. G. Zhou, Z. N. Xu, Y. M. Chen, G. C. Guo, J. Mater. Chem. A, 2018, 6, 2327-2336.

[75] J. Xie, Q. Zhang, L. Gu, S. Xu, P. Wang, J. Liu, Y. Ding, Y. F. Yao, C. Nan, M. Zhao, Y. You, Z. Zou, Nano Energy, 2016, 21, 247-257.

[76] L. Zhuang, J. Jin, H. D. Abrun, J. Am. Chem. Soc., 2007, 129, 11033-11035.

[77] L. Huang, X. Zhang, Q. Wang, Y. Han, Y. Fang, S. Dong, J. Am. Chem. Soc., 2017, 140, 1142-1147.

[78] Y. Liao, G. Yu, Y. Zhang, T. Guo, F. Chang, C. J. Zhong, J. Phys. Chem. C, 2016, 120, 10476-10484.

[79] X. Zhao, J. Zhang, L. Wang, H. X. Li, Z. Liu, W. Chen, ACS Appl. Mater. Interfaces, 2015, 7, 26333-26339.

[80] G. Fu, X. Yan, Z. Cui, D. Sun, L. Xu, Y. Tang, J. B. Goodenough, J. M. Lee, Chem. Sci., 2016, 7, 5414-5420.

[81] M. E. Scofield, C. Koenigsmann, L. Wang, H. Liu, S. S. Wong, Energ. Environ. Sci., 2015, 8, 350-363.

[82] B. Y. Xia, H. B. Wu, N. Li, Y. Yan, X. W. Lou, X. Wang, Angew. Chem. Int. Ed., 2015, 54, 3797-3801.

[83] C. Wang, Y. Zhang, Y. Zhang, P. Xu, C. Feng, T. Chen, T. Guo, F. Yang, Q. Wang, J. Wang, M. Shi, L. Fan, S. Chen, ACS Appl. Mater. Interfaces, 2018, 10, 9444-9450.

[84] N. Zhang, L. Bu, S. Guo, J. Guo, X. Huang, Nano Lett., 2016, 16, 5037-5043.

[85] X. Yu, D. Wang, Q. Peng, Y. Li, Chem., 2013, 19, 233-239.

[86] D. Wu, W. Zhang, D. Cheng, ACS Appl. Mater. Interfaces, 2017, 9, 19843-19851.

[87] L. Gu, L. Qian, Y. Lei, Y. Wang, J. Li, H. Yuan, D. Xiao, J. Power Sources, 2014, 261, 317-323.

[88] Z. K. Ghouri, S. Al-Meer, N. A. M. Barakat, H. Y. Kim, Sci. Rep., 2017, 7, 1738.

[89] H. Zhang, C. D. Gu, M. L. Huang, X. L. Wang, J. P. Tu, Electrochem. Commun., 2013, 35, 108-111.

[90] J. Zhan, M. Cai, C. Zhang, C. Wang, Electrochim. Acta, 2015, 154, 70-76.

[91] Z. Pu, I. S. Amiinu, D. He, M. Wang, G. Li, S. Mu, Nanoscale, 2018, 10, 12407-12412.

[92] C. C. L. McCrory, S. Jung, I. M. Ferrer, S. M. Chatman, J. C. Peters, T. F. Jaramillo, J. Am. Chem. Soc., 2015, 137, 4347-4357.

[93] X. Zhang, X. Yu, L. Zhang, F. Zhou, Y. Liang, R. Wang, Adv. Funct. Mater., 2018, 28, 1706523.

[94] Y. F. Xu, M. R. Gao, Y. R. Zheng, J. Jiang, S. H. Yu, Angew. Chem. Int. Ed., 2013, 52, 8546-8550.

[95] M. Gong, W. Zhou, M. C. Tsai, J. Zhou, M. Guan, M. C. Lin, B. Zhang, Y. Hu, D. Y. Wang, J. Yang, S. J. Pennycook, B. J. Hwang, H. Dai, Nat. Commun., 2014, 5, 4695.

[96] H. Li, Q. Zhang, X. Wang, S. Chen, L. Song, Y. Zhang, X. Sun, L. Gu, X. Jia, Nat. Commun., 2018, 9, 2452.

[97] S. Bai, C. Wang, M. Deng, M. Gong, Y. Bai, J. Jiang, Y. Xiong, Angew. Chem. Int. Ed., 2014, 53, 12120-12124.

[98] P. Rheinländer, S. Henning, J. Herranz, H. A. Gasteiger, ECS Trans., 2013, 50, 2163-2174.

[99] M. Bao, I. S. Amiinu, T. Peng, W. Li, S. Liu, Z. Wang, Z. Pu, D. He, Y. Xiong, S. Mu, ACS Energy Lett., 2018, 3, 940-945.

[100] P. Wang, K. Jiang, G. Wang, J. Yao, X. Huang, Angew. Chem. Int. Ed., 2016, 55, 12859-12863.

[101] P. Wang, X. Zhang, J. Zhang, S. Wan, S. Guo, G. Lu, J. Yao, X. Huang, Nat. Commun., 2017, 8, 14580.

[102] P. Jiang, Q. Liu, C. Ge, W. Cui, Z. Pu, A. M. Asiri, X. Sun, J. Mater. Chem. A, 2014, 2, 14634.

[103] Z. Wang, X. Ren, Y. Luo, L. Wang, G. Cui, F. Xie, H. Wang, Y. Xie, X. Sun, Nanoscale, 2018, 10, 12302-12307.

[104] T. Chao, X. Luo, W. Chen, B. Jiang, J. Ge, Y. Lin, G. Wu, X. Wang, Y.
Hu, Z. Zhuang, Y. Wu, X. Hong, Y. Li, Angew. Chem. Int. Ed., 2017, 129, 16263-16267.

[105] L. Fu, F. Yang, G. Cheng, W. Luo, Nanoscale, 2018, 10, 1892-1897.

[106] J. Tian, Q. Liu, A. M. Asiri, X. Sun, J. Am. Chem. Soc., 2014, 136, 7587-7590.

[107] R. Zhang, X. Wang, S. Yu, T. Wen, X. Zhu, F. Yang, X. Sun, X. Wang, W. Hu, Adv. Mater., 2017, 29, 1605502.

[108] C. Tang, N. Cheng, Z. Pu, W. Xing, X. Sun, Angew. Chem. Int. Ed., 2015, 54, 9351-9355.

[109] F. X. Ma, H. B. Wu, B. Y. Xia, C. Y. Xu, X. W. Lou, Angew. Chem. Int. Ed., 2015, 54, 15395-15399.

[110] C. Tang, R. Zhang, W. Lu, L. He, X. Jiang, A. M. Asiri, X. Sun, Adv. Mater., 2017, 29, 1602441.

[111] S. Fu, B. Zhang, H. Hu, Y. Zhang, Y. Bi, Catal. Sci. Technol., 2018, 8, 2789-2793.

[112] Y. Liu, S. Liu, Z. Che, S. Zhao, X. Sheng, M. Han, J. Bao, J. Mater. Chem. A, 2016, 4, 16690-16697.

[113] M. I. Jamesh, J. Power Sources, 2016, 333, 213-236.

[114] V. Vij, S. Sultan, A. M. Harzandi, A. Meena, J. N. Tiwari, W. G. Lee, T. Yoon, K. S. Kim, ACS Catal., 2017, 7, 7196-7225.

[115] H. W. Man, C. S. Tsang, M. M. J. Li, J. Mo, B. Huang, L. Y. S. Lee, Y. C. Leung, K. Y. Wong, S. C. E. Tsang, Chem. Comm., 2018, 54, 8630-8633.

[116] J. Zhou, Y. Dou, A. Zhou, L. Shu, Y. Chen, J. R. Li, ACS Energy Lett., 2018, 3, 1655-1661.

[117] J. X. Feng, H. Xu, Y. T. Dong, S. H. Ye, Y. X. Tong, G. R. Li, Angew. Chem. Int. Ed., 2016, 55, 3694-3698.

[118] S. Anantharaj, S. R. Ede, K. Sakthikumar, K. Karthick, S. Mishra, S. Kundu, ACS Catal., 2016, 6, 8069-8097.

[119] A. Damjanovic, A. Dey, J. O. M. Bockris, J. Electrochem. Soc., 1996, 113, 739-746.

[120] T. Reier, M. Oezaslan, P. Strasser, ACS Catal., 2012, 2 , 1765-1772.

[121] T. Zhang, S. C. Li, W. Zhu, Z. P. Zhang, J. Gu, Y. W. Zhang, Nanoscale, 2017, 9, 1154-1165.

[122] M. Sung, J. Kim, Int. J. Hydrogen Energy, 2018, 43, 2130-2138.

[123] J. Liu, Y. Zheng, Y. Jiao, A. Vasileff, Z. Wang, Z. Lu, A. Vasileff, S. Z. Qiao, Small, 2018, 14, e1704073.

[124] Y. Yang, M. Zhou, W. Guo, X. Cui, Y. Li, F. Liu, P. Xiao, Y. Zhang, Electrochim. Acta, 2015, 174, 246-253.

[125] X. Han, X. Tong, G. Wu, N. Yang, X. Y. Guo, Carbon, 2018, 129, 245-251.

[126] Y. Li, P. Hasin, Y. Wu, Adv. Mater., 2010, 22, 1926-1929.

[127] Y. Wang, D. Liu, Z. Liu, C. Xie, J. Huo, S. Wang, Chem. Commun. 2016, 52, 12614-12617.

[128] C. Dong, T. Kou, H. Gao, Z. Peng, Z. Zhang, Adv. Energy Mater., 2018, 8, 1701347.

[129] Y. Chen, C. Dong, J. Zhang, C. Zhang, Z. Zhang, J. Mater. Chem. A, 2018, 6, 8430-8440.

[130] P. Chen, K. Xu, Z. Fang, Y. Tong, J. Wu, X. Lu, X. Peng, H. Ding, C. Wu, Y. Xie, Angew. Chem. Int. Ed., 2015, 54, 14710-14714.

[131] J. S. Kim, B. Kim, H. Kim, K. Kang, Adv. Energy Mater., 2018, 8, 1702774 .

[132] L. Chen, H. Zhang, L. Chen, X. Wei, J. Shi, M. He, J. Mater. Chem. A, 2017, 5, 22568-22575.

[133] B. Hua, M. Li, J. L. Luo, Nano Energy, 2018, 49, 117-125.

[134] F. Lu, M. Zhou, Y. Zhou, X. Zeng, Small, 2017, 13, 1701931.

[135] K. Liu, C. Zhang, Y. Sun, G. Zhang, X. Shen, F. Zou, H. Zhang, Z. Wu, E. C. Wegener, C. J. Taubert, J. T. Miller, Z. Peng, Y. Zhu, ACS Nano, 2017, 12, 158-167.

[136] Y. Jin, S. Huang, X. Yue, H. Du, P. K. Shen, ACS Catal., 2018, 8, 2359-2363. 
[137] X. Lin, X. Li, F. Li, Y. Fang, M. Tian, X. An, Y. Fu, J. Jin, J. Ma, J. Mater. Chem. A, 2016, 4, 6505-6512.

[138] L. Trotochaud, J. K. Ranney, K. N. Williams, S. W. Boettcher, J. Am.
Chem. Soc., 2012, 134, 17253-17261.

[139] J. R. Swierk, S. Klaus, L. Trotochaud, A. T. Bell, T. D. Tilley, J. Phys. Chem. C, 2015, 119, 19022-19029.

\title{
一维纳米材料在能源电催化中的研究进展 \\ 李 苹 ${ }^{\mathrm{a}, \mathrm{b}}$, 陈 卫 $^{\mathrm{a}, \mathrm{b}, *}$ \\ ${ }^{a}$ 中国科学院长春应用化学研究所电分析化学国家重点实验室, 吉林长春130022 \\ ${ }^{\mathrm{b}}$ 中国科学技术大学应用化学与工程学院, 安徽合肥 230026
}

\begin{abstract}
摘要: 随着社会的快速发展, 人类对能源的需求不断增加, 化石能源的过度消耗造成了严重的环境污染和能源危机, 引起 全球各国的广泛关注. 为解决这一问题, 需要大力发展高效清洁的新能源转化装置. 直接甲醇燃料电池和全水分解两种能 源转化装置, 因其高效率、低排放、低操作温度等优点, 被认为是目前最具潜力的可再生能源. 两种电化学体系能源转化 过程中涉及的四个半反应分别是氧气还原反应(ORR)、甲醇氧化反应(MOR)、阴极氢气析出(HER)和阳极氧气析出(OER), 而ORR 和OER两个半反应由于动力学过程缓慢而成为甲醇燃料电池和全水分解两种装置转化效率的关键反应步骤, 其中 ORR反应过程中易发生两电子转移过程, 生成中间产物, 严重降低电流效率; OER反应涉及四电子转移和氧-氧键形成, 相 对于较易发生的二电子转移过程HER反应, 反应动力学缓慢是影响转化效率的主要原因. 因此, 开发先进的电催化剂, 尤 其是高效ORR和OER催化剂, 成为提高能源转化装置能量转化效率的关键. 在过去十几年里, 人们对基于贵金属铂、基于 过渡金属及非金属纳米材料的电催化剂进行了充分研究并取得了重要进展, 其中一维金属纳米材料(例如纳米线、纳米棒、 纳米管等)因其具有独特的表面结构及物理和化学性能, 表现出优越的电化学催化活性和较高的稳定性, 在能源电催化领 域具有潜在的应用价值. 本文总结了一维金属纳米材料作为电催化剂应用于上述四种催化反应的研究进展, 着重介绍了 四种催化反应过程的反应机理、催化剂性能提升策略及其在催化反应过程中活性位的变化规律.

首先对涉及到的四个半反应在不同电解质溶液中的反应过程和机理进行了详细介绍, 并分别讨论几种反应在热力学 和动力学过程上的主要障碍. 然后通过近年来的相关研究进展, 讨论了影响电催化剂催化活性的几种因素. 其中, 催化剂 的组成、不同量或不同种类的异质原子掺杂往往会使金属催化剂的电子结构发生不同程度的改变, 从而影响催化剂的性 能. 通常, 催化剂的电化学活性面积越大, 暴露出的活性位点越多, 越容易使催化剂活性位点与反应物接触, 从而提高催化 活性及加速传质过程. 因此, 很大一部分工作致力于提高纳米结构催化剂的有效活性面积, 用于电催化反应. 另外, 表面结 构和晶面的调控可以控制纳米材料的电催化专一性和选择性, 提高催化效率. 而纳米材料的电子传输能力也会对其催化 活性产生较大影响. 最后总结了提高一维金属纳米电催化剂催化活性的有效策略, 为进一步设计高性能电催化剂提供了 参考.
\end{abstract}

关键词: 一维金属纳米材料; 燃料电池; 全水分解; 电催化剂; 能源转化

收稿日期: 2018-08-31. 接受日期: 2018-10-08. 出版日期: 2019-01-05.

*通讯联系人. 电话/传真: (0431)85262723; 电子信箱: weichen@ @ ciac.ac.cn

基金来源：国家自然科学基金(21575134，21633008，21773224); 国家重点研发计划(2016YFA0203200); 王宽诚率先人才计划“卢 嘉锡国际团队项目”.

本文的电子版全文由Elsevier出版社在ScienceDirect上出版(http://www.sciencedirect.com/science/journal/18722067). 